\title{
What is the value of entrepreneurship? A review of recent research
}

\author{
C. Mirjam van Praag · Peter H. Versloot
}

Accepted: 14 August 2007/Published online: 25 September 2007

(C) Springer Science+Business Media, LLC 2007

\begin{abstract}
This article examines to what extent recent empirical evidence can collectively and systematically substantiate the claim that entrepreneurship has important economic value. Hence, a systematic review is provided that answers the question: What is the contribution of entrepreneurs to the economy in comparison to non-entrepreneurs? We study the relative contribution of entrepreneurs to the economy based on four measures that have most widely been studied empirically. Hence, we answer the question: What is the contribution of entrepreneurs to (i) employment generation and dynamics, (ii) innovation, and (iii) productivity and growth, relative to the contributions of the entrepreneurs' counterparts, i.e., the 'control group'? A fourth type of contribution studied is the role of entrepreneurship in increasing individuals' utility levels. Based on 57 recent
\end{abstract}

C. M. van Praag ( ()

Amsterdam Center for Entrepreneurship, Roetersstraat 11, 1018 WB Amsterdam, The Netherlands

e-mail: C.m.vanpraag@uva.nl

C. M. van Praag · P. H. Versloot

University of Amsterdam, Amsterdam, The Netherlands

C. M. van Praag · P. H. Versloot

Tinbergen Institute, Amsterdam, The Netherlands

C. M. van Praag

Max Planck Institute of Economics, Jena, Germany

C. M. van Praag

IZA Institute for the Study of Labour, Bonn, Germany studies of high quality that contain 87 relevant separate analyses, we conclude that entrepreneurs have a very important-but specific-function in the economy. They engender relatively much employment creation, productivity growth and produce and commercialize high-quality innovations. They are more satisfied than employees. More importantly, recent studies show that entrepreneurial firms produce important spillovers that affect regional employment growth rates of all companies in the region in the long run. However, the counterparts cannot be missed either as they account for a relatively high value of GDP, a less volatile and more secure labor market, higher paid jobs and a greater number of innovations and they have a more active role in the adoption of innovations.

Keywords Entrepreneur - Entrepreneurship · Self-employment · Productivity . Economic development - Growth · Employment · Innovation · Patents · R\&D · Utility · Remuneration · Income

JEL Classification D24 - D31 - E23 . E24 $\cdot$ J21 $\cdot$ J28 $\cdot$ J31 $\cdot$ L26 $\cdot$ M13

\section{Introduction}

Almost without exception, academic studies on entrepreneurship are motivated by the economic benefits of entrepreneurship. Most studies refer to one 
or two academic studies showing that entrepreneurship indeed leads to substantial benefits in terms of, for instance, employment generation or innovations. However, whether the cited reference was one of the few out of many studies that 'happened' to find supportive evidence is not yet clear. This article examines to what extent recent empirical evidence can collectively and systematically substantiate this claim. Entrepreneurs and their counterparts are defined and compared in terms of their contribution to the creation of economic value. Hence, the aim is to review recent empirical literature that provides an (statistically supported) answer to the following question: What is the economic value of entrepreneurs in comparison to their counterparts, i.e., non-entrepreneurs? Based on empirical studies into this subject, we arrive at four measures to quantify the economic value of entrepreneurs. Hence, we answer the following particular questions: What is the contribution of entrepreneurs to (i) employment generation and dynamics, (ii) innovation, and (iii) productivity and growth, relative to the contributions of the entrepreneurs' counterparts, i.e., the 'control group'? A fourth type of contribution that we study is the role of entrepreneurship in increasing individuals' utility levels.

Surprisingly, given the relevance of showing the relationship between entrepreneurship and economic outcomes, this article is the first review of the (primary) empirical literature in this area. More precisely, it is the first review of high-quality economics and management studies, focusing on various types of contributions that entrepreneurs can make to the economy in terms of quantifiable measures and evaluating the entrepreneurs' performance in these areas relative to their counterparts, i.e., larger, older or incumbent firms. In these senses, our study is unique. ${ }^{1}$

Besides emphasizing what our study might contribute, it is also worthwhile to acknowledge what it does not contribute. Economic or management

\footnotetext{
1 To our knowledge, five previous and recent studies are somewhat related: Acs and Audretsch (2005) on entrepreneurship and innovation; Carree and Thurik (2003) on entrepreneurship and economic growth from a macroeconomic perspective; Biggs (2002), discussing small and medium-sized firms (SMEs) and employment generation and innovation; Caves (1998), focusing on firm entry, exit and turnover, as well as firm growth and production efficiency, and, finally, Sutton (1997) on employment generation.
}

theories about why and how entrepreneurs would contribute more or less to specific aspects of economic value creation, such as employment or innovation, are not included. They are beyond the scope of our study and provided elsewhere, as for instance in Parker (2004) and in many of the studies reviewed. We only provide an (rather thorough) overview of empirical studies to evaluate the extent of contributions to economic value creation of entrepreneurs in practice. $^{2}$

The remainder of the article is structured as follows. Section 2 elaborates on the definitions of the key variables, i.e., entrepreneurs, the entrepreneurs' counterparts, employment generation and dynamics, innovation, productivity and growth, and the indicators used in the literature of utility derived from entrepreneurship. Moreover, we discuss the details of the sample selection procedure and sample statistics. In Sect. 3, the entrepreneur's relative contribution to employment is evaluated in terms of levels and growth. Moreover, employee remuneration is compared as an indicator of employment quality. Section 4 discusses entrepreneurs' relative contributions to innovation in terms of the production, commercialization and adoption of innovations. In Sect. 5, the contribution of entrepreneurs to productivity and value and productivity growth is assessed in terms of value added, labor productivity, and total factor productivity. Section 6 focuses on utility levels derived from entrepreneurship as compared to wage employment in terms of expected income levels, income volatility, and job satisfaction levels. Section 7 concludes.

\section{Data: sample selection and definitions}

\subsection{Sample selection procedure}

The available empirical literature has been categorized and selected according to systematic rules. These rules should result in a database with sufficient

\footnotetext{
${ }^{2}$ Moreover, we do not relate the behavior of entrepreneurial firms to economic outcomes, as is done in, for instance Wynarczyk and Watson (2005); Maes et al. (2005), or Norton and Moore (2006). Nor do we assess how institutional factors affect the growth and productivity of entrepreneurial and other firms differently, i.e., Hartarska and Gonzalez-Vega (2006).
} 
coverage (i.e., representative of the population of published and unpublished studies) and precision (i.e., provides high-quality information on the issue).

First, we focus on the most recent studies published in journals with the highest impact (and probably quality). That is, only primary English language studies from the AA or A ranked economic journals, as defined by the widely acknowledged Dutch Tinbergen Institute Research School, were considered (see http://www.tinbergen.nl). In addition, two very influential small business and entrepreneurship field journals, i.e., The Small Business Economics Journal (the leading entrepreneurship journal in the field of economics) and The Journal of Business Venturing (the leading entrepreneurship journal in the field of management), and three top management journals (Strategic Management Journal, the Academy of Management Journal, and Administrative Science Quarterly) ${ }^{3}$ were considered in this review. Books or book chapters are not reviewed and only referred to for relevant background.

Second, to describe results that apply to the current economic environment, and that are based on stateof-the-art research methods, only literature published in the period 1995 to March $2007^{4}$ - the date of completing the sample-pertaining to industrialized countries is reviewed. ${ }^{5}$ Recent discussion papers2002 to March 2007-were considered an additional source of literature, providing the most recent results. ${ }^{6}$

Third, an initial—exploratory-search of studies analyzing the 'value of entrepreneurship' showed that the foremost benefits analyzed in the literature pertain to employment, innovation, productivity and growth, and individuals' utility levels. These constitute the four categories of benefits we analyze (and define

\footnotetext{
3 Management Science is included in the Tinbergen list.

${ }^{4}$ In an important exception, relevant articles from a forthcoming special issue of the Small Business Economics Journal have been included.

${ }^{5}$ Given the structural differences between industrialized and less-developed countries the contribution of entrepreneurship is likely to differ (Van Stel et al. 2005; Sternberg and Wennekers 2005; Wennekers et al. 2005).

6 The primary (virtual) search engines and databases for working papers we use are Google Scholar, the Social Science Research Network (SSRN), and working papers series of wellknown research institutes such as NBER, CEPR and IZA.
}

below). The initial search was based on keywords ${ }^{7}$ and JEL-codes in search engines and databases such as Google Scholar, EconLit, Ebsco host, and Social Science Research Network (SSRN).

The before final requirement prescribes that studies employ a quantitative measure of the outcome variables defined, i.e., employment, innovation, productivity and growth, and individuals' utility levels. The final requirement imposed is that the study contains an explicit empirical test of whether the quantifiable contribution of the entrepreneur(ial firm) is significantly different from the contribution of the control group, i.e., the counterparts. Thus, eligible studies include observations on (the rate of) firms/individuals that can be considered entrepreneurial as well as (the rate of) firms/ individuals that can be considered counterparts, based on the definitions given below.

\subsection{Definitions of the entrepreneur and the counterpart}

Common empirical definitions of 'the entrepreneur' or 'entrepreneurial firm' are employed in this study. The terms 'entrepreneur' and 'entrepreneurial firm' are used interchangeably. Entrepreneurial firms are defined as firms that satisfy one of the following conditions: (i) They employ fewer than 100 employees; (ii) They are younger than 7 years old; (iii) They are new entrants into the market. Hence, the 'control' group - or counterpart-to which the contribution of entrepreneurial firms is compared consists of firms that (i) employ more than 100 employees; (ii) are older than 7 years; (iii) incumbent firms. The section on utility examines individuals and thus requires other definitions. There, entrepreneurs are selfemployed or the owner-manager of an incorporated business, where the size or age of her firm is not a deciding factor. The control group is formed by employees.

Entrepreneurship is studied in the relevant literature in terms of these definitions both at the micro-level, i.e., at the level of the individual firm

\footnotetext{
$\overline{7}$ Examples are, used as single search terms and in combinations: entrepreneurship, economic development, economic growth, productivity, firm growth, employment (generation), job creation, utility, income, remuneration, innovation, patents, $\mathrm{R} \& \mathrm{D}$, job duration.
} 
or entrepreneur, and at the macro-level. In the latter case, the rate of (i) small firms, (ii) young firms, (iii) new firms, or (iv) entrepreneurs is measured at the regional or national level.

But how did we arrive at these definitions? In line with the Schumpeterian entrepreneur, the definition of the entrepreneur as being a market entrant (or a young firm that has recently entered the market) is straightforward and these definitions-entrants or young firms-are often employed in entrepreneurship research. Though most entrepreneurial firms are small, ${ }^{8}$ small firms are not always entrepreneurial and identifying small firms as entrepreneurs is therefore less straightforward, though a common practice among entrepreneurship policy makers and academics to which we comply. Moreover, following the majority of empirical studies of entrepreneurship, we view individuals who have started up a business or who own a business, i.e., who are self-employed or the owner-manager of an incorporated business, as entrepreneurs too. This may be inappropriate as selfemployment is often not associated with the creation of firms, whereas entrepreneurship is. Nevertheless, without an accepted superior empirical definition, we chose not to deviate from what seems to be conventional. $^{9}$

Moreover, with respect to the boundaries (between young and old or small and large firms) there is no theoretical basis to feed our choices. Instead, again, we followed apparent conventions. With respect to size, several measures (in terms of personnel or sales) are used. For the most often used size measure, i.e., personnel, the most common cut-off point is 100 employees. However, various size classes are often observed and analyzed separately, e.g., 10-20, 20-50, 50-100, 100+ employees. In such cases, again, 100 employees is used as the boundary between small and large. A significant proportion of studies relates the measures of an economic contribution to continuous firm size measures. In that case, the actual boundary between entrepreneurs and the control group is less

\footnotetext{
$\overline{{ }^{8} \text { Nurmi (2006) }}$ analyzes the determinants of the start-up sizes of plants.

${ }^{9}$ Luger and Koo (2005) acknowledge the problem of the ad hoc nature of the definitions and measurement of the entrepreneur(ial firm) used in the literature. They arrive at a 'superior empirical definition', which is however difficult to employ in existing databases.
}

relevant and conclusions result about the relationship between a measure of economic benefits and firm size (entered linearly or otherwise). The same holds for the measure 'firm age', and if boundaries are chosen they are often set at 5 or 7 years. Please note that the various definitions are often, though implicitly, combined, i.e., entrants are young by definition and rarely employ more than 100 employees. The resulting sample size does not allow a distinction between the various definitions of entrepreneur(ial firm)s; for example, we do not pursue analyses of the extent to which young firms are innovative as compared to new market entrants or small firms. This is a limitation of our study.

\subsection{Indicators of contributions to economic outcomes}

Employment Firms may contribute to the amount of employment generated or to the quality of employment. Firm growth, measured by the number of jobs created (relative to the size of the firm), is often used as an indicator of the quantity of employment generated. The quality of employment is measured in terms of the remuneration offered to employees. The primary indicators used are wage levels, benefits (e.g., health insurance), and the use of productivityrelated-pay (PRP). Job satisfaction levels of the employees in entrepreneurial firms relative to employees in counterpart firms came up as a final indicator of employment quality.

Innovation is a broad concept for which a multitude of indicators is employed. Regarding a firm's innovative output, i.e., the production of innovations, both measures of its quantity and quality are used. For quantity, commonly used empirical measures include research and development expendituresalthough it measures input rather than outputpatents, and the introduction of new products or technologies. The quality of those innovations is indicated by patent citations and the importance of the innovations, however measured. Moreover, the commercialization of innovations as well as the adoption of innovations are used as measures of contributions to economic value through innovation.

Productivity and growth are measured by (a firm's or region's contribution to) a country's gross domestic product (GDP) or GDP growth. Therefore, studies 
are included in our review if they measure a firm's (or region's) value added, labor productivity-i.e., a firm's (or region's) contribution to the GDP per worker-or total factor productivity (TFP), i.e., output per unit of capital and labor input combined. Studies measuring the value and/or growth of any of these indicators of productivity and growth are considered relevant and are discussed.

Utility Indicators for an entrepreneur's individual utility relative to employees relate to specific sources of utility. The first source is any form of remuneration, i.e., expected incomes. Risk is another element affecting the utility of risk-averse individuals (negatively). Finally, job satisfaction levels are used as an indicator of utility.

\subsection{Search and sample statistics}

All issues of each selected journal and working paper series within the relevant publication period were studied. If an article title suggested relevance, its abstract was analyzed to determine inclusion into the review. Finally, the article's content was studied to check whether the study actually fulfills all requirements defined before. This method of gathering literature is a thorough attempt to create an exhaustive sample of relevant studies-given the requirements-but is sensitive to errors. For example, we may miss a study if the title is formulated too generally for our purpose. The potential for this error was reduced by checking each study whose title only vaguely hinted at the topic of interest. Another way to check whether the sample was complete was to browse the references of the studies selected. If one such reference seemed relevant the study was checked. Hence, if not exhaustive, our sample may be representative of the relevant literature.

The sample consists of 57 unique studies that measure the contribution of entrepreneurs relative to their counterparts to one or more of the indicators defined. Table 1 shows the number of studies per publication category (economics AA journals, economics A journals, small business journals, management journals and working papers) and year.

Two-thirds of the studies in the sample have been published in Small Business and Entrepreneurship journals, the remainder elsewhere, i.e., mostly in economics journals, or not yet. One-third of the studies has been published in 2004 or later and more than half of them after 2002. This holds for all categories of studies. The periods observed by the various studies in the sample are obviously less recent. Most analyses pertain to the 90 s and 80 s of the previous century.

The 57 studies include 87 observations in total, i.e., several studies analyze various relevant relationships. Table 2 shows their distribution over the (sub-) categories of economic value indicators.

The number of studies in the first three main outcome categories, i.e., employment, innovation, and productivity and growth, is similar. The category 'utility' is smallest with 14 studies. More than half of the studies on employment belong to the sub-category of employment creation, whereas the vast majority of the remainder of studies in this category study the extent to which entrepreneurs contribute to the quality of employment. Half of the innovation studies focus on the relative contribution of entrepreneurs to the production of innovations, whereas a quarter of the studies measure the contribution of entrepreneurs to the commercialization and adoption of innovations, respectively. Productivity and growth are most often quantified in terms of labor productivity, whereas the relative utility levels of entrepreneurs are indicated by incomes in most studies, and less frequently by measures of income volatility (negative) or satisfaction.

Table 3 shows the definitions of the entrepreneur used in the various categories of studies. Studies on employment study small(er) versus large(r) firms and, but to a lesser extent, new versus incumbent firms. The definition of entrepreneurship used in the studies on innovation is more scattered. The same holds for studies on productivity and growth. The category of studies on utility uses 'self-employment' or business ownership as the dominant definition of the entrepreneur.

Most of our observations result from analyses at the individual firm (or entrepreneur) level. However, the 'employment' and 'productivity and growth' categories also include studies based on observations at more aggregate levels (regions, industries, or even countries).

We conclude that the results and conclusions described in what follows are mainly based on recent articles in high-quality economics and small business and entrepreneurship journals and working papers. 
Table 1 Studies per publication category and publication year

\begin{tabular}{|c|c|c|c|c|c|c|}
\hline Publication year/publication category & EcAA & EcA & SB & $\mathrm{M}$ & WP & Total \\
\hline 1995-1997 & 0 & 4 & 8 & 0 & $\mathrm{X}$ & 12 \\
\hline 1998-2000 & 2 & 3 & 7 & 1 & $X$ & 13 \\
\hline 2001-2003 & 0 & 3 & 6 & 0 & 4 & 13 \\
\hline 2004-2007 & 0 & 1 & 13 & 1 & 4 & 19 \\
\hline Total & 2 & 11 & 34 & 2 & 8 & 57 \\
\hline
\end{tabular}

EcAA and EcA refer to economic journals with this (Tinbergen Institute) rank, SB refers to Small Business and Entrepreneurship journals, M to Management journals, and WP refers to Working Papers

Table 2 Studies per outcome indicator (sub-)category

\begin{tabular}{|c|c|c|c|}
\hline $\begin{array}{l}\text { Main category of } \\
\text { outcome indicator }\end{array}$ & $\#$ & $\begin{array}{l}\text { Sub-category of } \\
\text { outcome indicator }\end{array}$ & $\#$ \\
\hline \multirow[t]{3}{*}{ Employment } & \multirow[t]{3}{*}{27} & Employment generation & 15 \\
\hline & & Employment dynamics & 2 \\
\hline & & Employee remuneration & 10 \\
\hline \multirow[t]{3}{*}{ Innovation } & \multirow[t]{3}{*}{21} & Production & 10 \\
\hline & & Commercialization & 6 \\
\hline & & Adoption & 5 \\
\hline \multirow[t]{3}{*}{ Productivity and growth } & \multirow[t]{3}{*}{25} & Value added & 7 \\
\hline & & Labor productivity & 11 \\
\hline & & Total factor productivity & 7 \\
\hline \multirow[t]{3}{*}{ Utility } & \multirow[t]{3}{*}{14} & Income levels & 8 \\
\hline & & Volatility & 3 \\
\hline & & Satisfaction & 3 \\
\hline Total & 87 & & 87 \\
\hline
\end{tabular}

The results pertain in most cases to small firms in the 1980s and 1990s.

\section{Contributions to employment}

This section reviews the recent evidence of the role of entrepreneurial firms in generating employment, in terms of quantity, dynamics, and quality, where the latter refers to aspects of employees' remuneration.

\subsection{Generation of employment}

The empirical literature on the generation of employment can be categorized based on whether aggregated (macro or meso) or disaggregated (micro) data are analyzed. The unambiguous results lead to the conclusion that entrepreneurial firms have a disproportionately high contribution to the creation of jobs.

Based on aggregated data, Baldwin (1998) concludes, based on changes in employment shares of size classes of Canadian manufacturing plants, that the smallest size class, i.e., plants employing fewer than 100 employees, has increased its employment share in the period 1973-1992, whereas the larger size classes experienced decreasing employment shares. Johansson (2005)—studying active Swedish IT firms in the period 1994-1998-establishes a Ushaped relationship between an industry's average firm size and its employment growth, with a minimum value for employment growth at an average firm size of around 240 employees. Shaffer (2006) arrives at a similar conclusion, also based on aggregated data, namely at the county/sector level in the US. Shaffer's study makes an interesting first

Table 3 Frequency of using the various definitions of the entrepreneur

\begin{tabular}{llllll}
\hline Definition of entrepreneur(ial firm) & (i) Small & (ii) Young & (iii) New & (iv) Self-empl. & Total \\
\hline Employment & 18 & 1 & 6 & 2 & $\mathbf{2 7}$ \\
Innovation & 14 & 3 & 4 & 0 & $\mathbf{2 1}$ \\
Productivity and growth & 15 & 4 & 4 & 2 & $\mathbf{2 5}$ \\
Utility & 0 & 0 & 0 & 14 & $\mathbf{1 4}$ \\
Total & $\mathbf{4 7}$ & $\mathbf{8}$ & $\mathbf{1 4}$ & $\mathbf{1 8}$ & $\mathbf{8 7}$ \\
\hline
\end{tabular}

(i), (ii), (iii), and (iv) refer to the definitions for the entrepreneur introduced in Sect. 2.2 


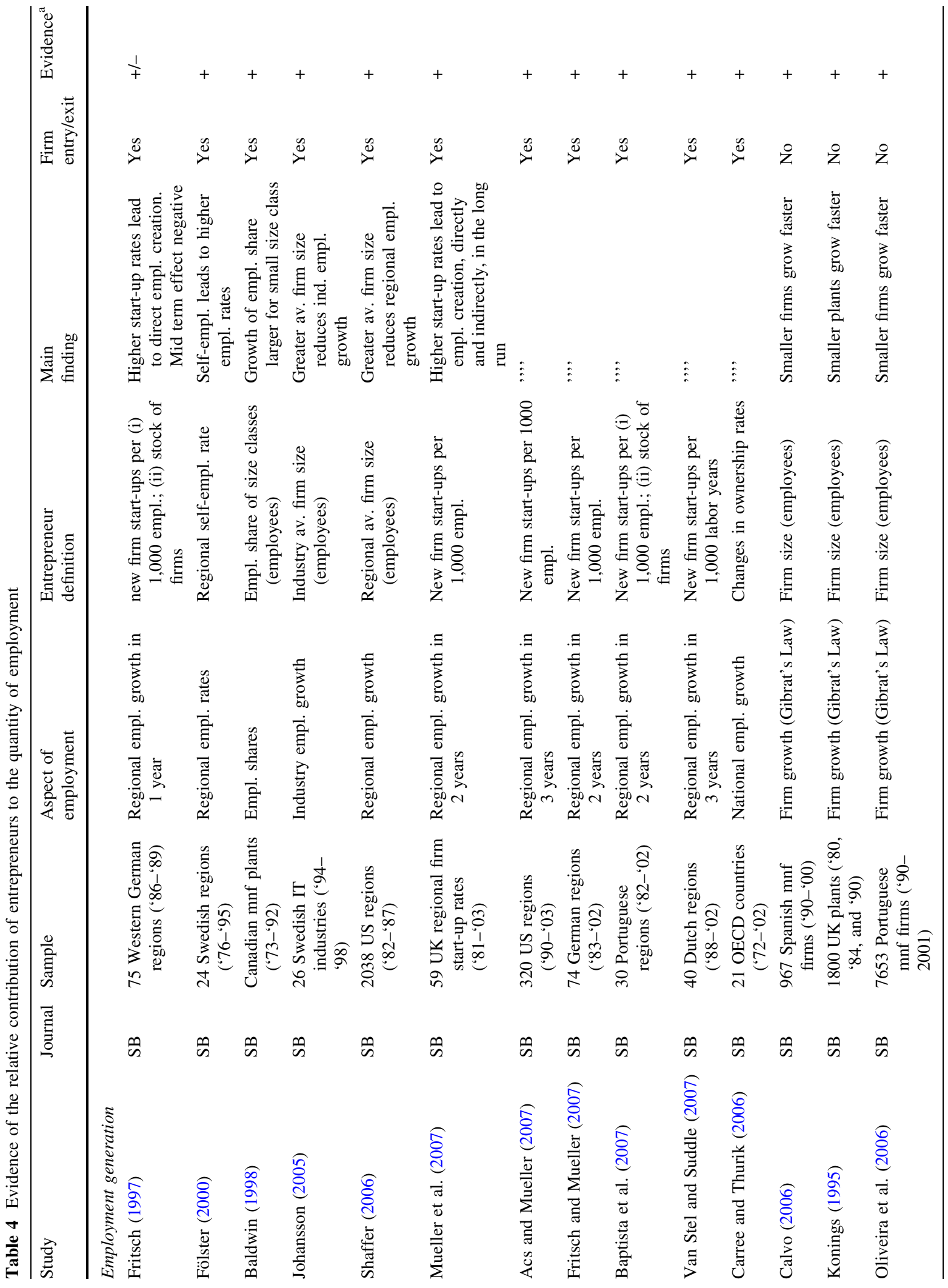


attempt to including the measurement of externalities in terms of job creation: "Most previous studies of employment patterns have focused on job changes within individual firms, overlooking potentially important aggregate effects that may reflect externalities and which are essential to an assessment of overall welfare.[...] In most cases, smaller establishments are found to be associated with faster subsequent growth rates of employment, both within and across sectors." (p. 439).

A recent stream of research, actually initiated by Michael Fritsch (2007), studies aggregated data, mostly at the regional level to analyze both direct and indirect effects of entrepreneurial activity on employment growth (and other outcomes). Start-ups, or market entries lead to new business development, whereas incumbent firms might be forced to dissolve by the increased competition of the new firms. More indirectly, the new businesses and the removal of older, perhaps less efficient businesses, might lead to improved competitiveness and economic growth. In particular, as a consequence of taking into account these indirect effects, another relevant question arises: How many years after the inception of new firms do these effects of business turnover, improved efficiency, and economic growth arise? What are the short term and what are the long-term effects? These questions are answered in a handful of recent studies.

The conclusions of the various studies based on regional data for various countries and years are all similar: Higher start-up rates are associated with higher immediate levels of employment (in these new firms themselves). However, after some years the relationship with employment growth is negative due to the competitive pressure that leads (inefficient) incumbents to shed labor or exit the market. In the longer run though, the net effect is positive due to increased competitiveness. Table 4 shows that Fritsch (1997) and Fritsch and Mueller (2007) study German regions; Mueller et al. (2007) British; Acs and Mueller (2007) US regions; Baptista et al. (2007) Portuguese regions; Van Stel and Suddle (2007) Dutch and Fölster (2000) Swedish regions. ${ }^{10}$ Based on country level data, Carree and Thurik (2006) find evidence for the same pattern: Increased business ownership rates are shown to go together with an instantaneous small effect on

$\overline{10}$ The studies by Fritsch (1997) and Fölster (2000) are limited to the short (or medium term). 
employment generation, a mid term negative effect and a long-term positive effect.

Studies using disaggregated data to examine the relationship between firm size or age and the proportional number of jobs a firm has created follow a framework derived from (actually one of the assumptions underlying) Gibrat's 'Law of Proportionate Effect' (Gibrat 1931). The derivation of Gibrat's Law is based on the assumption that mean growth rates are the same for all firm sizes. A very popular generalization of Gibrat's framework, allowing for heterogeneous growth rates, is the following (see equation 9.5, p. 214 in Parker 2004):

$\ln q_{i t+1}=\alpha_{i}+\beta \ln q_{i t}+u_{i t+1}$

Estimating the coefficient of firm size shows whether large $(\beta>1)$ or small $(\beta<1)$ firms have grown faster and is relevant as long as size is measured in terms of the number of employees. Studies in our sample that follow this methodology are Calvo (2006, Spain), Hart and Oulton (1996, UK), Konings (1995, UK), and Oliveira and Fortunato (2006, Portugal). All four lead to the conclusion that smaller (surviving) firms have the highest percentage-rate growth. Thus, proportional to their size, small firms created more jobs than did large firms (see Table 4 for sample sizes and years studied).

Another method for examining job creation (and employment dynamics, see below) by small versus large firms based on micro-data is most often ascribed to Davis and Haltiwanger (1992) and relies on descriptive analysis. Therefore, those studies do not belong to this review. However, due to the impact of this kind of studies and their widespread use to analyze employment (dynamics), we discuss seven of these studies (which are not included in the tables) briefly. These studies have an advantage over those using the framework based on Gibrat's Law that they share with studies based on aggregated data like regions or industries: They include the effects of firm entry and exit.

Simply put, the method sorts firms by whether they have created or destroyed jobs, i.e., grown or shrunk, and by size class. Whether a firm has created (destroyed) jobs depends on whether it has a larger (smaller) size (in employees) at time $t+1$, than at time $t$. Thus, employment creation is caused by firms that have grown or entered the market, while employment destruction is caused by firms that have shrunk or exited the market. Employment generated by a given size class is the sum of the jobs created by the growing (or entering) firms within that size class. Employment destroyed is analogously defined. These numbers are converted into job creation and destruction rates by dividing them by the average size of the firms within the size class. Whether an entire size class (i.e., all growing and shrinking firms within a size class) has created jobs depends on the 'net employment growth rate' which is given by subtracting the job destruction rate from the job creation rate.

Davis and Haltiwanger (1992) find that in US manufacturing (1972-1986) the size class with between 1 and 99 employees has higher job creation and job destruction rates than larger firms. The effects offset and ultimately result in rather similar net employment growth rates across size classes. Davis et al. (1996), studying the US manufacturing sector in 1972-1988, also find similar net employment growth rates for various size classes. Younger firms have higher net employment growth rates, see Davis and Haltiwanger (1992). Baldwin and Picot (1995, Canada) and Broersma and Gautier (1997, Netherlands) show that smaller manufacturing firms have higher net employment growth. Picot and Dupuy (1998) show the same result for the Canadian economy in general. Thus, although the studies may find different rates, smaller and younger firms tend to have higher net employment growth rates. Therefore, the net contribution to employment generation will be higher for entrepreneurs, relative to their own size.

The negative relationship between firm growth and size (or age) that is found in three categories of studies, each having specific drawbacks (and advantages), ${ }^{11}$ is consistent with numerous earlier empirical studies. In fact, as Parker puts it more broadly (2004, p. 215) "While many disparate results have been published, one of the most important and widely verified is the following: Firm growth rates are decreasing in firm size among firms of the same age; and are decreasing in firm age among firms of the same size." The upper panel of Table 4 shows the unambiguous results.

The bottom panel of Table 4 shows that worker reallocation is higher in entrepreneurial firms (Burgess

\footnotetext{
11 Studies using aggregated data may miss important determinants of the employment generation process, studies using the framework based on Gibrat's Law may neglect the effects of firm entry and exit, and studies using the framework attributed to Davis and Haltiwanger make no statistical comparisons.
} 
Table 5 Regression results with and without controlling for worker heterogeneity (WH)

\begin{tabular}{|c|c|c|c|c|c|c|}
\hline \multirow[t]{2}{*}{ Study } & \multirow[t]{2}{*}{ Regressor } & \multirow{2}{*}{$\begin{array}{l}\text { w/o WH } \\
\beta\end{array}$} & \multirow{2}{*}{$\begin{array}{l}\mathrm{w} / \mathrm{WH} \\
\beta\end{array}$} & \multicolumn{3}{|c|}{ Additional details } \\
\hline & & & & Country & Period & $N$ \\
\hline \multicolumn{7}{|c|}{ Brown and Medoff (2003, p. 684). Dependent variable: Ln(wage/hour) } \\
\hline & Age of business/10 & $0.022 * * * *$ & -0.001 & USA & 1992 & 1,067 \\
\hline & Ln(age of business) & $0.042 * *$ & $-0.035 * *$ & & & \\
\hline \multicolumn{7}{|c|}{ Winter-Ebmer and Zweimuller (1999, p. 90). Dependent variable: Ln(wage) } \\
\hline & Size class $0-4$ & Ref. & Ref. & Switzerland & 1991-1996 & 7,453 \\
\hline & Size class $5-9$ & $0.046^{* * * *}$ & -0.010 & & & \\
\hline & Size class $11-99$ & $0.095^{* * * *}$ & $0.025 * *$ & & & \\
\hline & Size class $100+$ & $0.129 * * * *$ & $0.030 * * *$ & & & \\
\hline \multicolumn{7}{|c|}{ Troske (1999, p. 19). Dependent variable: Ln(wage) } \\
\hline & Log firm size & $0.033 * * * *$ & $0.026^{* * * *}$ & USA & 1989 & 129,901 \\
\hline & Log plant size & $0.064 * * * *$ & $0.047 * * * *$ & & & \\
\hline
\end{tabular}

$* * * *, * * *$ and $* *$ denote significance levels of $0.1,1$ and $5 \%$, respectively

et al. 2000) and small firms have relatively volatile growth rates over time (Burgess et al. 2000; Lever, 1996). We conclude that employment dynamics are larger in entrepreneurial firms. This conclusion is supported by the 'Davis and Haltiwanger' method that generates a measure of the employment dynamics of a size class, i.e., the 'job reallocation rate', the sum of the employment creation and destruction rates. Young and small firms contribute relatively much (little) to employment dynamics (security), see Davis and Haltiwanger (1992); Davis et al. (1996), Baldwin and Picot (1995), Broersma and Gautier (1997), and Picot and Dupuy (1998) for support for various countries, sectors, and time periods. ${ }^{12}$

\subsection{Remuneration and satisfaction of employees}

All studies on 'firm size wage differentials' reach a similar conclusion: Smaller and younger firms pay their employees lower wages. For example, Wunnava and Ewing (2000) find that in 1989, small US firms ( $<100$ employees) pay their male employees $18 \%$ less than otherwise identical employees of medium sized firms (with 101-499 employees) and 27\% less than large firms (+500 employees).

\footnotetext{
12 A large (relative) effect of entry and exit of firms on employment dynamics has been established using the Davis and Haltiwanger framework by Spletzer (2000) and Neumark et al. (2005) (see also Anyadike-Danes et al. 2005). Firm entry and exit are most likely for smaller and younger firms (see Calvo 2006; Parker 2004; Heshmati 2001).
}

The wage premium earned by employees in larger firms has three observed causes: First, entrepreneurs employ individuals with lower levels of human capital in terms of education and experience (Troske 1999; Winter-Ebmer and Zweimuller 1999). Second, entrepreneurs offer lower returns to those personal characteristics (Oosterbeek and Van Praag 1995). Finally, entrepreneurs run firms in which the capitalskill complementarity is lower (Troske 1999). Workers working in more capital intensive firms are paid higher wages and larger firms are more capital intensive than smaller firms. On top of the differences in wages between smaller and larger firms that can be explained by these factors, an unexplained difference in wages remains. As Troske (1999) summarizes: "However, none of the explanations can fully account for the employer sizewage premium. In the end there remains a large, significant, and unexplained premium paid to workers of large employers." (p. 15).

Brown and Medoff (2003), who study firm age wage differentials, show that the positive correlation between firm age and employee wages even turns into a negative relationship when controlling for worker heterogeneity. "The higher wages paid by established firms are completely explained by the observable characteristics of their workers. It is not just experience and tenure but also education, occupation, and other demographic characteristics." (p. 693).

Table 5 shows an overview of the studies in our sample on firm size (age) wage differentials with(out) controls for worker heterogeneity: The firm size wage 
differential does not disappear but becomes smaller when controlling for worker heterogeneity, whereas the firm age wage differential even turns negative (for the largest part of the age distribution) based on one observation only.

Besides finding that large firms pay their workers higher wages, Wunnava and Ewing (2000) also derive that the probability a given individual will receive benefits, such as medical insurance, life insurance, maternity leave, and retirement benefits increases with firm size. Moreover, Cowling (2001) establishes that entrepreneurs use productivityrelated-pay (PRP) schemes less frequently than the counterparts in 1996. Hence, it seems that entrepreneurs are less likely to offer employees other forms of remuneration.

Winter-Ebmer and Zweimuller (1999) infer job satisfaction levels from actions taken by employees in Switzerland: on-the-job-search (for alternative employment) and actual job changes. Both activities are undertaken less frequently by employees of larger firms (p. 92) and we can infer that employees of smaller firms must be less satisfied with their job.

In contrast, Frey and Benz (2003), who examine actual scores on a job satisfaction questionnaire, find that employees of smaller German, British, and Swiss firms have higher average job satisfaction scores than employees of larger firms. This is consistent with the findings by Clark and Oswald (1996) for UK employees. The mean satisfaction scores for small ( $<25$ employees), medium (25-199), and large $(>199)$ firms are significantly different and show that employees of the smallest firms are more satisfied. Furthermore, the percentage of workers reporting to be 'very satisfied' is highest in the smallest firms.

Thus, these three studies show ambiguous results. Based on two direct measures, we conclude that employees in entrepreneurial firms are more satisfied. However, this is in conflict with the result of one indirect measurement of job satisfaction. All studies pertain to Europe.

Table 6 summarizes the results pertaining to employee remuneration and satisfaction. It shows that entrepreneurs pay their workers lower base wages and offer fewer benefits and less productivity-related-pay than the counterparts. As such, we should conclude that entrepreneurs have a lower contribution to the quality of facilitated employment than the counterparts. However, this lower contribution is partly justifiable by recognizing that entrepreneurs employ individuals with lower levels of skills, and run firms with lower levels of capitalskill complementaries. Nevertheless, job satisfaction levels of employees in entrepreneurial firms tend to be higher. Apparently, more research is required to explain why employees are more satisfied with less pay in entrepreneurial firms.

\subsection{General summary of the contributions to employment}

The studies on the generation of employment and employment dynamics generally show that entrepreneurial firms grow, proportionately, faster than other firms. Moreover, in the long run, entrepreneurial firms create positive externalities leading to more employment, also in other, i.e., older, larger, and incumbent firms. Although entrepreneurs create more jobs, the jobs they create are less secure due to higher volatility and higher probabilities of firm dissolution. Furthermore, entrepreneurs offer their employees lower remuneration levels than these individuals would earn if they were employed by large firms. Moreover, employees in non-entrepreneurial firms obtain more benefits and are more frequently remunerated on a performance related basis. Nevertheless, employees in entrepreneurial firms-although they earn less and face higher risks of losing their job-are more satisfied with their jobs than employees in the control group of firms. Future research might explain some of the remaining puzzles.

\section{Contributions to innovation}

\subsection{The quantity and quality of innovations}

To quantify a firm's innovativeness, researchers have focused on three measures that we discuss in what follows. The first is the firm's Research and Development (R\&D) expenditures. Second, the number of patents it produces, and third, the number of new products or technologies introduced. The measurement of quality is related to patent citation rates, and the (subjectively) assessed importance of new products/technologies. 


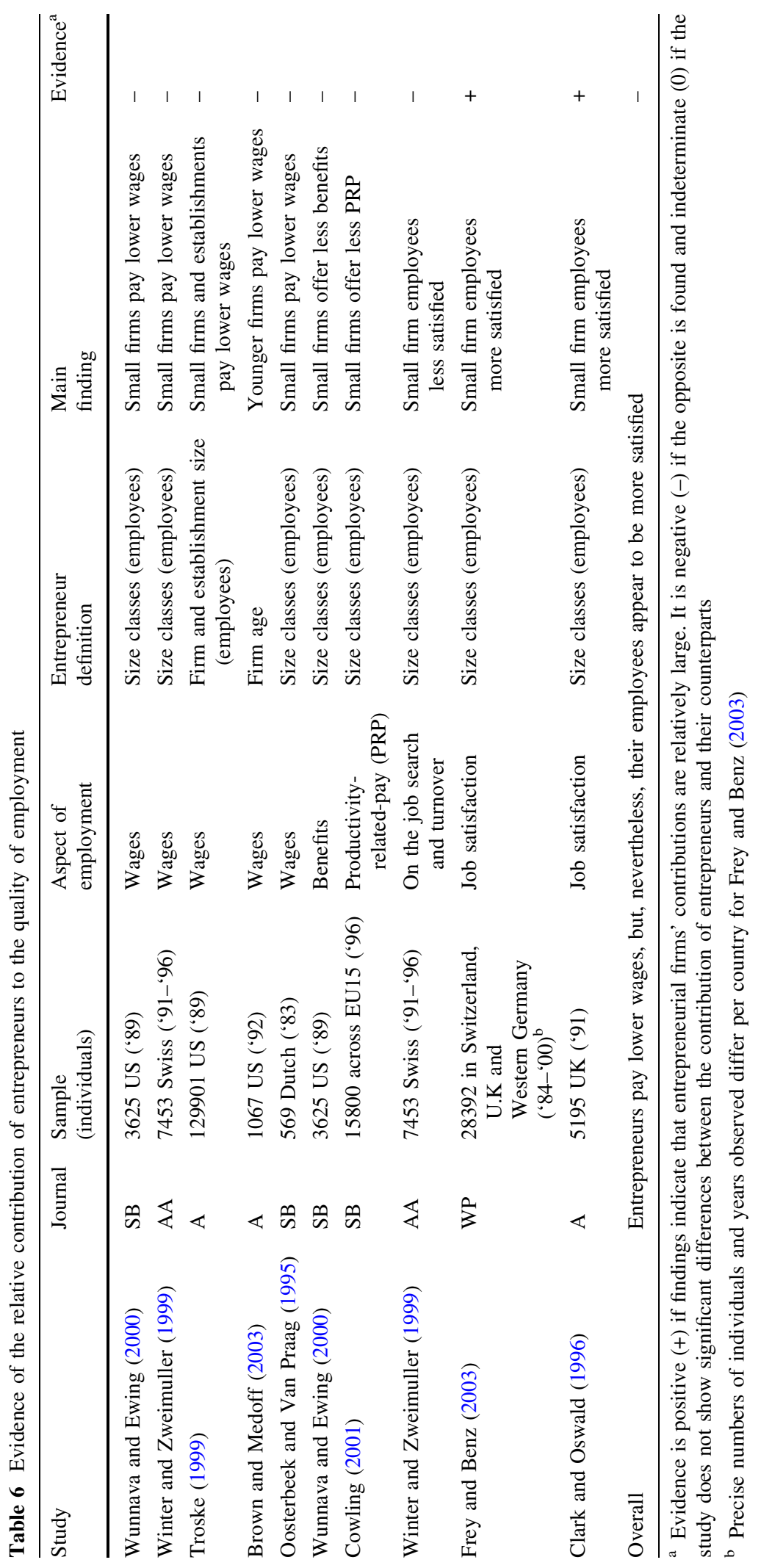


$R \& D$ expenditures are considered an input for innovations. And since "It is said that industrial R\&D, particularly, basic research, tends to be less developed than the socially optimal level" (Koga 2005, p. 53), higher levels of R\&D expenditure are considered valuable. Castany et al. (2005) compare the mean $R \& D$ expenditure per employee of large and small Spanish firms (cut-off point at 200 employees) and find that large firms have allocated around 2.5 times more resources to R\&D than small firms (in 1990 and 1994). In contrast, Arvanitis (1997) finds identical levels of R\&D expenditure per employee for the largest part of the Swiss firm size distribution. Based on these two studies, we can only conclude that entrepreneurs devote no more resources per employee to $\mathrm{R} \& \mathrm{D}$ than the control group. However, Yang and Huang (2005) find evidence that R\&D expenditures induces higher growth rates for small firms (in the Taiwan electronics sector). This would imply that each dollar spent on R\&D in a small firm is more valuable than a dollar spent in a large firm.

Patents are used as a proxy for a firm's level of innovations. There is conclusive evidence that entrepreneurs produce fewer patents than their counterparts. Almeida and Kogut (1997) and Sørensen and Stuart (2000) find such evidence for the US semiconductor and biotech industries.

The measure of innovation that is related to new products and technologies is most often quantified based on subjective answers from firm-managers as to whether they have introduced a new product or technology. So far, studies have examined firms from the manufacturing sector only. Love and Ashcroft (1999) find that the number of innovations increases with plant size in Scottish plants. Huergo and Jaumandreu (2004) show that the probability that a Spanish firm introduces a product or process innovation is higher for large firms (more than 500 workers) than small firms (20 or fewer workers). The difference is 37 percentage points for process innovations and 27 percentage points for product innovations. They find the same sort of relationship between the probability of innovating and firm age.

The finding that larger firms (are more likely to) introduce more innovations is not striking: Larger firms may simply have more product lines to improve upon. Love and Ashcroft (1999) use a second measure of innovativeness, i.e., innovations per employee, and find that this measure actually decreases with firm size. Hence "smaller plants are indeed more 'innovation intensive' than their larger counterparts" (Love and Ashcroft 1999, p. 107). ${ }^{13}$ In other words, they produce innovations more efficiently.

One study distinguishes between mere product improvements and radically new products, i.e., Acs and Gifford (1996, US) and finds that larger firms introduce more radically new products, as a fraction of total product innovations.

Arvanitis (1997) uses firm-managers' subjective assessments of the importance of their firm's innovative behavior to gauge quality. Smaller firms turn out to assess their own innovative behavior as a less important contributor to economic value creation. A more objective measure of quality is patent citations (corrected for self-citations). If a patent is cited more often, it is reasonable to assume that the underlying product has given rise to more patents and innovations. Sørensen and Stuart (2000) find that in the semiconductor industry the time between patent citations made by other firms than the patent holder increases with firm age. However, they do not find evidence of this (or any other) relationship between firm size and citations in the biotech industry.

Based on somewhat ambiguous results we conclude cautiously as follows. ${ }^{14}$ Entrepreneurs invest no more in innovation than their counterparts and they produce fewer innovations. However, the quality of their innovations may be higher and these innovations

\footnotetext{
${ }^{13}$ Love and Ashcroft observe plants not firms. However, they control for whether the plant is part of a multi-plant firm and this is insignificantly related to the number of innovations and the number of innovations per employee.

${ }^{14}$ The ambiguity of the results has several causes. Various definitions and indicators of 'innovativeness' are used, most of which are (somewhat) distorted, i.e., they do not capture all relevant aspects of innovation. For example, large firms rely more on in-house $R \& D$, small firms more on university research (Audretsch and Vivarelli 1996). Thus, R\&D expenditures do not fully reflect innovativeness. Moreover, R\&D spending may be underreported by small firms (Roper 1999). Other potential research flaws are that patents may not represent economically viable products but reflect a firm's fear of expropriation (Kortum and Lerner 2000); new products may be product improvements with limited value creation. A final issue is that a limited number of industries and countries is examined. For instance, the rapidly growing service industry is not covered by research (the reviewed studies).
} 
seem to be produced more efficiently. If anything, this section shows a shortcoming in analyzing innovativeness: benchmarking the number of innovations against the size of the firm is not common.

\subsection{The commercialization of innovations}

Two measures of commercialization are used: first, (the probability of) sales from innovations in general, and second, (the probability of) generating sales given some specific innovation. Using the first measure, Brouwer and Kleinknecht (1996) perform two analyses, both based on Dutch firm data from the early nineties. Based on the first analysis they conclude that larger firms are more likely than smaller firms to have sales from innovative products. The second analysis leads to the conclusion that smaller firms in the service sector outperform larger firms based on the share of their total sales realized with innovative products, "given that a firm has some sales of innovative products" (p. 196). However, for firms in the manufacturing sector, they find no significant firm size effect. Thus, entrepreneurs in the service sector are less likely to have sales from innovative products, but if they do have such sales, they will derive a higher fraction of their total sales from those innovative products. Hence, this is weak evidence in favor of entrepreneurs who are relatively good at commercializing their innovations. Czarnitzki and Kraft (2004) generalize this latter result based on a sample of firms with and without any sales from innovative products in seven European countries: the share of sales from innovations is higher for smaller firms.

The second measure of commercialization, i.e., the generation of sales with a given innovation, is analyzed by Lowe and Ziedonis (2006) and Dechenaux et al. (2003). The first study finds that "Start-ups and established firms are equally likely to commercialize inventions generated by the same university department" (p. 180), whereas the second study concludes that start-ups realize a first sale quicker than incumbent firms. Hence, if anything, the likelihood of realizing sales from a university invention is higher for entrepreneurs than for their counterparts.

Moreover, the royalty revenues received by the university from start-ups are higher than royalties received from established firms, suggesting "start-ups outperform established firms" (Lowe and Ziedonis 2006, p. 182). On the other hand, start-ups continue to pursue unsuccessful commercializations longer than established firms, suggesting start-ups destroy more value.

In sum, we have the following observations: The likelihood of turning innovations into sales is lower for entrepreneurs, whereas their share of sales from innovations - as a fraction of total sales-in general is higher than for other firms. Entrepreneurs are also more likely to generate sales and higher levels of royalty from a given (university) invention. However, entrepreneurs were found to destroy more value through prolonging unsuccessful commercialization strategies. Thus, the level of commercialization of entrepreneurs can be concluded to be relatively high. Nevertheless, the economic benefit of commercialization by entrepreneurs vis-à-vis their counterparts depends on the trade-off between resources wasted and value created by entrepreneurs over and above that wasted and created by other firms. This trade-off has not yet been examined.

\subsection{The adoption of innovations}

The type of innovations adopted by firms having been in the spotlight recently is ICT-related technologies. Chandrashekaran and Sinha (1995) examine the volume and timing of 'adopting' personal computers (PCs) by 3,236 US firms in 1978-1984. They find that first purchases are made earlier by smaller firms, whereas larger firms buy, unsurprisingly, larger volumes.

BarNir et al. (2003) survey 150 US magazine publishing firms in 2001 and find that older firms use the Internet more frequently for specific business purposes, e.g., communication with customers (see p. 802). However, the difference between firms of different ages, though significant, is small. Lucchetti and Sterlacchini (2004) do not find a difference across firm sizes in the use of Internet and e-mail by nonproduction workers in Italy, both for general applications and as a marketing tool. However, larger firms use more complicated ICT, e.g., Intranet or data-servers, more frequently than small firms (in the year 2000).

In sum, smaller firms were found to adopt ICTproducts earlier than large firms, but its volume and use may be independent of firm size. Small firms are 
less inclined to adopting high-cost innovations, such as data-servers. Thus, entrepreneurs and counterparts are equally likely to adopt low-cost innovations, whereas the counterparts are more likely to adopt higher cost innovations.

\subsection{General summary of the contributions to innovation}

Table 7 shows the rather complex results pertaining to the contribution of entrepreneurs in terms of innovation. Entrepreneurs invest no more in innovation than their counterparts and they produce fewer innovations. The quality of their innovations may be higher and these innovations seem to be produced more efficiently, i.e., entrepreneurs produce more patents per employee and they are cited more often. Concerning the commercialization of innovations, the levels are relatively high for entrepreneurs (in terms of the share in sales). Nevertheless, the relative benefit of commercialization by entrepreneurs vis-àvis their counterparts is not clear yet. Furthermore, entrepreneurs and counterparts are equally likely to adopt low-cost innovations, whereas the counterparts are more likely to adopt higher cost innovations. To conclude, entrepreneurs and their counterparts contribute equally importantly to the innovativeness of societies. However, they serve different goals in terms of quality, quantity, and efficiency, as well as in terms of producing (and adopting) more radical (and higher cost) innovations. It might be interesting to note that our results are not in contradiction to results obtained at the country level. Based on a panel of 36 countries, Wennekers et al. (2005) show that the correlation between the extent of entrepreneurial activity in a country and a country's innovative capacity ("a country's potential to produce a stream of commercially relevant innovations," p. 297) is positive for more developed countries such as the US and Europe. Likewise, Acs and Varga (2005) find a positive relationship between entrepreneurial activity and technological change in the European Union.

\section{Contributions to productivity and growth}

The contributions of entrepreneurs to productivity and growth are measured by their relative contribution to components of GDP, i.e., total value added, and labor and factor productivity. A distinction is made between contributions to the level of GDP (Sect. 5.1) and the growth of GDP (Sect. 5.2).

\subsection{Levels of value added and productivity}

A direct measure of contributions to a country's GDP is a firm's value added, since GDP is the sum of the amount of value added per firm, summated over all firms. The second main indicator is related to the efficiency of production or the contribution to GDP per worker, i.e., labor productivity. Total factor productivity (TFP) is used as the final indicator. It is often referred to as the 'residual' or the indicator of "technical progress" and is defined as output per unit of capital and labor combined.

The relationship between entrepreneurship and levels of value added (unlike growth of value added) has been little studied and is not very insightful since value added is a type of size measure. Thus, the contribution of entrepreneurial firms (often small) to value added will be lower than for other firms.

The majority of the studies with respect to the value of labor productivity show that entrepreneurs have lower-or, at least, no higher values of labor productivity-than their counterparts. Disney et al. (2003) is the only study providing evidence that the labor productivity of entrepreneurial firms is relatively high: UK manufacturing establishments younger than 1 year, i.e., entrants, have an average annual labor productivity (output per person hour) that is $2.4 \%$ higher than for incumbent establishments, and 5\% higher than for exiting establishments.

On the contrary, Brouwer et al. (2005, Netherlands) relate Dutch manufacturing firms' value added and gross output to the cost of labor and find that both ratios increase with firm size. Thus, entrepreneurs appear to have lower average levels of labor productivity than their counterparts. Foster et al. (2006, US, retail trade sector) compare labor productivity levels of entrants, incumbents and exiting firms. Their results show that exiting establishments are far less productive than entering establishments, and entering and incumbent establishments have similar productivity levels. However, due to a major restructuring trend in the sector and period studied, "Among entering establishments, the establishments 


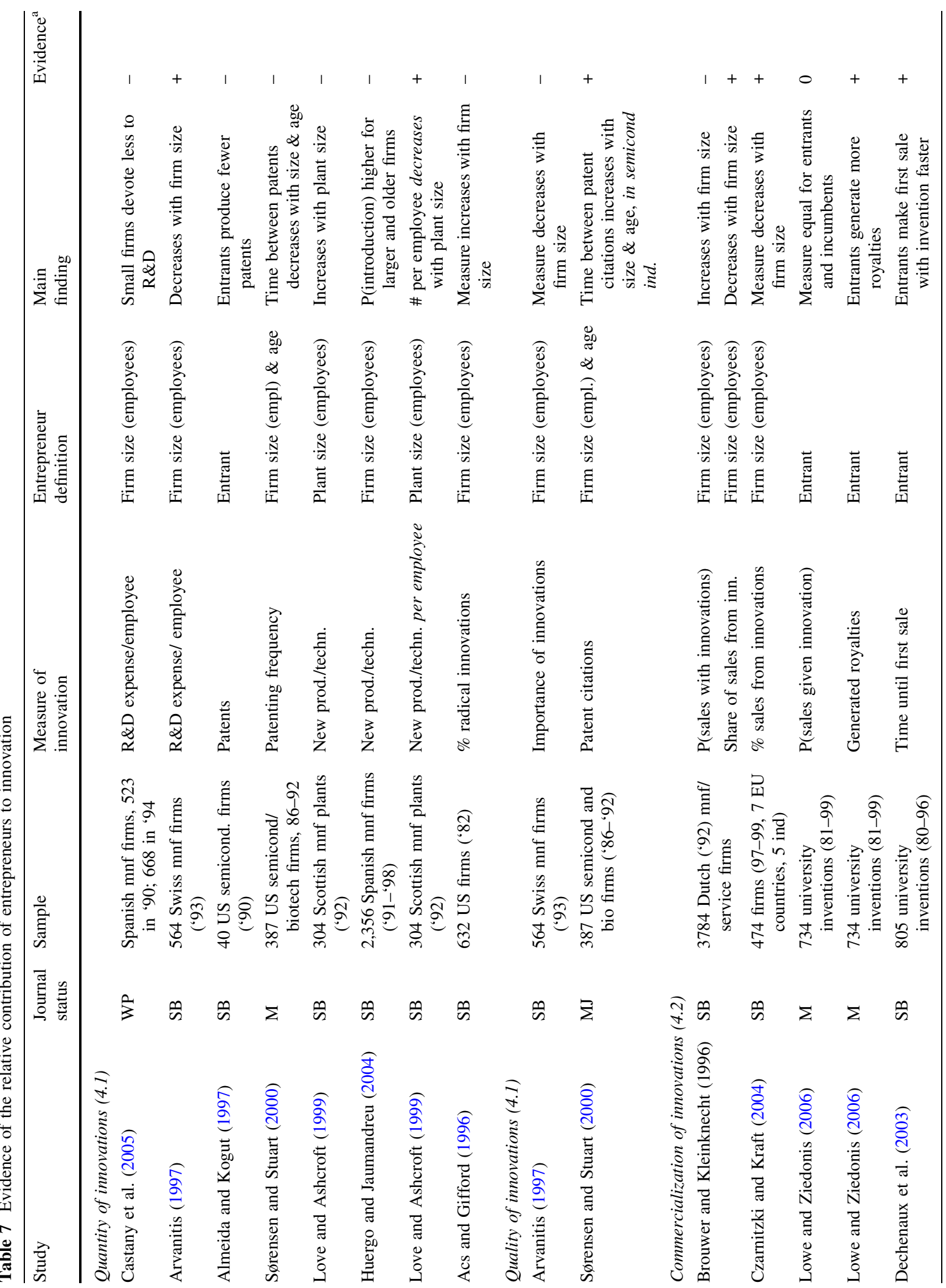


associated with a national chain have a very large productivity advantage relative to single unit incumbents" (p. 754) and single unit entrants. Therefore, national chains are likely to drive the average productivity of entrants up to a point where this group's productivity is insignificantly different from incumbent firms. Thus, although Foster et al. do not examine this, truly entrepreneurial entrants may be less productive than the other firms. ${ }^{15}$

Finally, Jensen et al. (2001) acknowledge several difficulties obscuring a comparison of productivity levels across plants of different ages. In fact, there are three different effects on productivity as plants grow older. The first is the positive age or experience effect, i.e., older plants are more productive due to the management accumulating experience, gains from learning by doing, or the achievement of economies of scale. Second, older plants are more productive due to survival: Samples of young plants include potential successful as well as potential failing plants, whereas samples of older plants are self-selected based on performance. Hence, the selection effect based on survival biases the results from a comparison of the productivity of younger and older plants in favor of older plants. Third, there is a possibly offsetting negative 'vintage' effect: The best-practice technologies are embodied in new capital, i.e., start-up plants. Hence, younger plants in a given year embody more productive technologies. They distinguish these three effects empirically and find that all three are sizeable. First, age has a positive effect on productivity, i.e., surviving plants improve their relative standing in the productivity distribution as they age. Second, selection matters. "Recent entrants show productivity levels below industry averages, but this is largely due to a large number of small, low-productivity plants that subsequently fail. Rapid failure of these plants leaves behind larger, high-productivity survivors" (p. 332). Third, vintage matters: "New plants embody better production technology and, even after controlling for labor quality and capital intensity, show higher

\footnotetext{
${ }^{15}$ It could though be the case that some chains franchise individual establishments, whereas others don't. Franchisees operate on their own account and risk and could therefore be considered entrepreneurs as opposed to employed managers of chain subsidiaries. However, neither Foster et al. (2006), nor Disney et al. (2003) make such a distinction.
} 
productivity than do earlier cohorts of entrants" (p. 332). Taken together, the effects entail a relatively low contribution of younger firms to labor productivity: Productivity increases significantly with plant age. However, once the quality of labor (using the cohort of entrants' average wages per hour worked as a proxy) and capital intensity are controlled for, productivity differentials with respect to age become insignificant. This implies that the differentials between older and younger plants may be due to older plants employing higher quality labor or having higher capital intensity. The conclusion might perhaps be generalized to explaining the results by Brouwer et al. (2005) that show that larger (instead of older) firms are more productive than smaller (instead of younger) firms. Jensen et al. (2001) confirm the virtual irrelevance of whether plant age or plant size is studied. The results described, pertaining mostly to manufacturing firms in various countries and time periods, are rather mixed, but mostly not in support of relatively high levels of entrepreneurs' labor productivity.

Total Factor Productivity (TFP) has been considered an important ingredient of a firm's or nation's production function ever since Solow (1957) introduced the concept as an indicator of the effect of technical change on productivity and a driver of economic growth. It is the multiplier $A$ in the production function, here shown in Cobb-Douglas form with two inputs, i.e., capital input $(K)$ and labor input $(L)$ :

$Y=A \times K^{\alpha} \times L^{1-\alpha}$

The level of $A$ is a measure of the efficiency of the use of production factors, whereas the change in $A$ over time measures efficiency changes. ${ }^{16}$ Empirical studies on the differences between entrepreneurial and non-entrepreneurial firms with respect to TFP deliver ambiguous results. Disney et al. (2003) find that entrants have higher average TFP levels than incumbents and exiting establishments, i.e., 3.9\% and $9.4 \%$, respectively. Castany et al. (2005, Spain) show

\footnotetext{
${ }^{16}$ However, Solow's interpretation only holds empirically if firms whose TFPs are compared use identical, or at least similar, production factor inputs. This reduces the applicability of TFP as an empirical indicator of contributions to economic development. Nevertheless it is a much studied driver of economic growth.
}

that the mean TFP levels of large (older) firms are (marginally) significantly higher than of small (younger) firms. The differences between the results of Disney et al. in favor of young firms and these of Castany et al. (2005) in favor of larger and older firms can possibly be traced back to the fact that Castany et al. exclude firms with fewer than 10 employees. Since entrants start out small, Castany et al. could have excluded the firms Disney et al. found to be most productive. Brouwer et al. (2005, Netherlands, manufacturing) corroborate the results by Castany et al. Moreover, Nguyen and Lee (2002, US, manufacturing) find that the returns-to-scale with respect to multiple factors is identical and constant for all size classes. Hence, their work supports "the proposition that small establishments are as efficient as large establishments" (p. 48). We conclude that TFP levels of entrepreneurs are not different from or lower than those of their counterparts.

The conclusion about the contribution to the levels of productivity of entrepreneurs relative to their counterparts, as indicated by labor and total factor productivity, is not clear cut. The mixed results tend to indicate that entrepreneurs have no higher, and probably lower, levels of productivity than their counterparts. Differences between entrepreneurs and their counterparts are insignificant (or attributable to specific factors) in many cases. Table 8 shows an overview of the results.

One important point remains to be discussed: The studies reviewed in this section use two distinct observation-levels, i.e., individual firms and individual plants/establishments, possibly leading to problems in interpreting and reconciling the results. That is, our observations are obtained from six unique studies of which four are based on samples of individual plants and two of firms. When observing plants, it is not clear whether the plant is operated by an entrepreneur, i.e., a single owner-manager, or is a subsidiary of a larger, non-entrepreneurial firm. Thus, studies observing plants produce results that may not pertain to entrepreneurs. The two studies at the firm level, that therefore apply to our definition of the entrepreneur, find results that are not in favor of a relatively large contribution of entrepreneurs to productivity.

One of the plant-observing studies, i.e., Foster et al. (2006), allows a distinction between single unit plants/establishments, and plants/establishments 


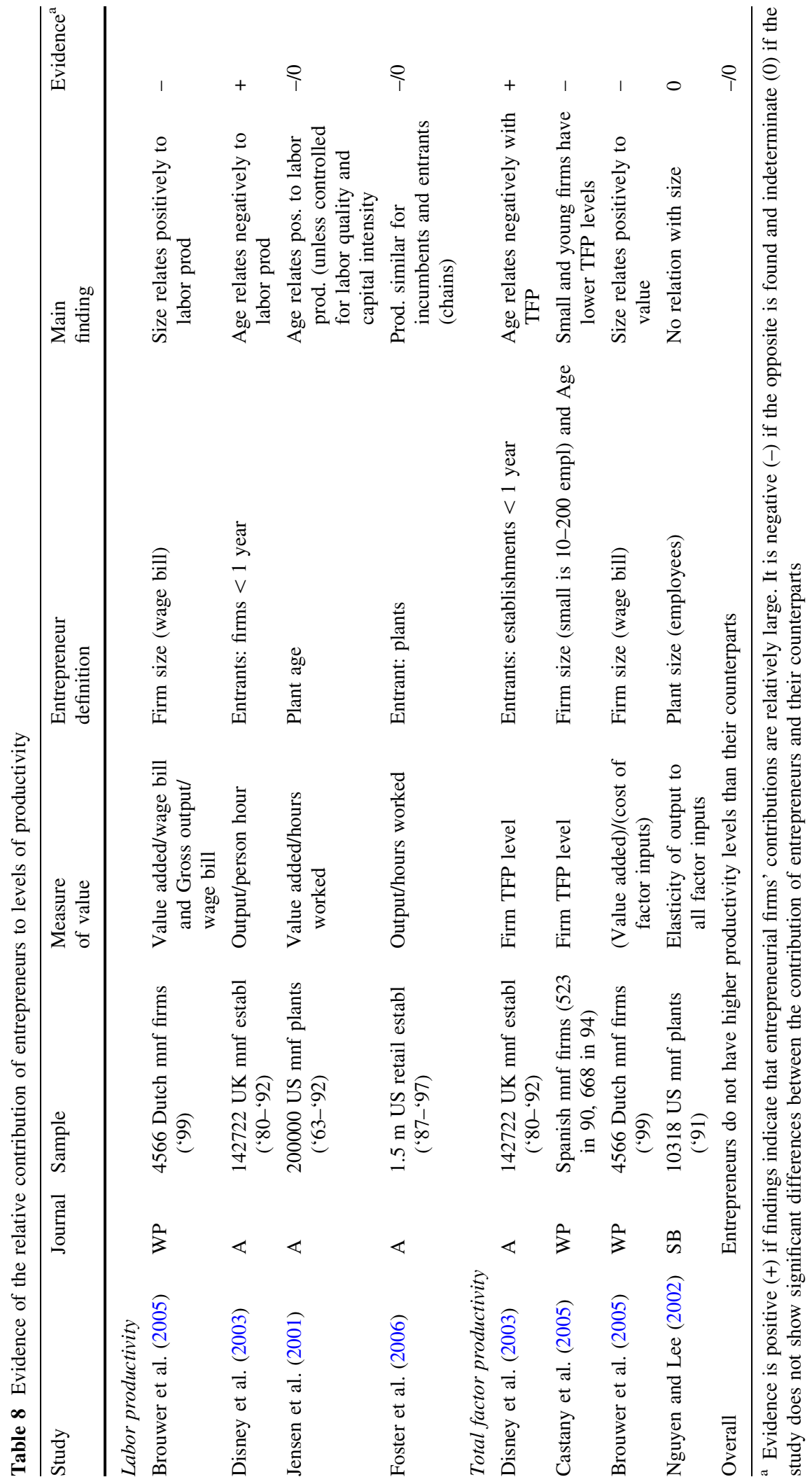


belonging to a larger group, where the former obviously corresponds to our notion of entrepreneurs. They find that the higher levels of labor productivity associated with entrants is mainly caused by the group of entrants that belong to a chain in the retail trade sector studied. Hence, based on this result we could ultimately degrade all results pertaining to analyses at the establishment level. However, the study by Foster et al. (2006) pertains to the retail trade sector, whereas the most commonly studied sector in this area is the manufacturing sector where chains are not as dominant in general and not among entrants in particular. ${ }^{17}$

\subsection{Growth of value added and productivity}

In general, researchers have shown more interest in the analysis of the growth of value added and productivity than in the analysis of their levels.

Growth of value added has been studied at the firm level (Brouwer et al. 2005; Rodríguez et al. 2003) and at more aggregated levels (Baldwin 1998; Carree 2002; Robbins et al. 2000; Carree and Thurik 2006). By and large, the results show that the entrepreneurs' growth of value added is relatively high. At the firm level, Brouwer et al. (2005) show that the growth rates in productivity, in terms of output and value added relative to the costs of the factors of production, decrease with firm size, i.e., smaller firms have higher productivity growth rates. Rodríguez et al. (2003, Spanish Canary Islands) use the framework of Gibrat's Law and corroborate this result.

Based on aggregated data, Baldwin (1998, Canada, manufacturing) shows increasing shipment shares of the smallest size class at the cost of those of larger size classes. Hence, economic activity has been shifted towards small firms (possibly without any actual growth of total shipment value, i.e., GDP).

\footnotetext{
17 Dunne et al. (1988) report that in the US manufacturing sector (1963-1982), "on average, single-plant firms account for $93.4 \%$ of the total number of firms in each year" (p. 500) and the remainder being multi-plant firms. Furthermore, 55.5\% of the entrants are single-unit firms, with the remainder being multi-plant firms (see p. 504). In contrast, out of all establishments observed by Foster et al., 64\% are single-unit establishments, and the remainder multi-unit plants (footnote 13, p. 753). Foster et al. do not show such statistics about entrants.
}

Whether the effect of such a shift is positive in terms of economic value added, depends on the relative performance of small versus large firms and the performance improvements of large firms due to the improved competitiveness as a consequence of more small firm activity. Audretsch et al. (2002) have studied the relationship between size class shares and economic growth and indeed find a positive effect of a larger small size class.

Robbins et al. (2000) provide direct support of the relatively large contribution of entrepreneurial firms to value added growth, also based on aggregated data and accounting for possible spillovers between large and small firms. By affecting productivity growth positively, the smallest businesses provide a relatively large indirect contribution to the growth of a state's value added. ${ }^{18}$ Carree (2002) supports this result by showing that increases in large firm employment shares lead to lower value added index changes. Thus, "on average, a shift towards small units has led to increased growth" (p. 248). Carree and Thurik (2006) relate the growth of the number of business owners as a percentage of the labor force to (national) GDP growth. They establish that the initial effect on GDP growth of a higher business ownership rate is positive and there is no significant evidence of business ownership having an indirect effect later on.

Thus, entrepreneurs' production value grows relatively fast in comparison to the control group according to all six studies. These unambiguous results have been found while using a definition of the entrepreneur based on firm size or new business formation and based on micro- as well as macro-data, where the latter incorporate spillover effects of entrepreneurial firms on their counterparts.

With respect to labor productivity growth, the results, also based on six-largely the same-studies, are more mixed. Three studies are based on aggregated data (Baldwin 1998; Robbins et al. 2000; Carree and Thurik 2006), whereas three studies are based on micro-data, one at the firm level (Brouwer et al. 2005), and two at the establishment level (Disney et al. 2003; Foster et al. 2006). Baldwin (1998) shows indirect evidence that the entrepreneurs' relative labor productivity has shrunk during

\footnotetext{
${ }^{18}$ Unlike Baldwin (1998), Robbins et al. (2000) define the performance measure at the state level, thereby including the possible effects of externalities between small and large firms.
} 
the period of his study, implying that the growth in productivity was smaller than that of the control group. Baldwin does not include possible spillover effects of small firms on large firms in his results.

Robbins et al. (2000) examine the relationship between the employment share of small businesses and a measure of labor productivity growth both defined at the (US) state level (and including possible spillover effects). Their result is opposite to Baldwin's, possibly due to large spillover effects. ${ }^{19}$ Carree and Thurik (2006) study to what extent and when, i.e., short versus long term, direct and indirect effects of new business creation are translated into increased labor productivity growth. They find evidence of a direct immediate (marginally significantly) positive effect. A longer term effect is insignificant.

Based on micro-data, Brouwer et al. (2005) support the result that the productivity of small firms grows faster than of large firms. Disney et al. (2003) decompose industry-wide labor productivity growth-based on individual establishment datainto (1) growth due to incumbent establishments increasing their labor productivity, so called 'internal restructuring', and (2) growth due to the entry and exit of establishments, i.e., the sum of the loss of labor productivity due to establishments exiting and the gain in labor productivity due to entrants, the so called 'external restructuring'. Disney et al. find that effects (1) and (2) are each responsible for around $50 \%$ of industry-wide productivity growth. Given that entrants are a small fraction of all establishments investigated, we infer that entrants have a relatively high contribution to labor productivity growth. ${ }^{20}$

\footnotetext{
${ }^{19}$ Defining small businesses as firms employing fewer than 20 employees, the employment share of this category has a significantly positive relation with productivity growth (p. 297). However, when defining the small business sector as firms employing fewer than 500 employees, the relationship turns out insignificant.

${ }^{20}$ However, in their study of labor productivity growth, Disney et al. (2003) make the same distinction between singleunit entrants and entrants belonging to chains as Foster et al. (2006) do in their studies of both the level and the growth of labor productivity. They then find that the effect of net entry, i.e., effect (2), is dominated by the latter type of entrants in the manufacturing sector, too. That is, "net entry by singles raised productivity growth, accounting for about $16 \%$ of overall [labor] productivity growth. Interestingly however, the net entry effect of establishment groups accounts for about double this amount."(p. 681). Hence, although single-unit entrants contribute to labor productivity growth in the manufacturing
}

Foster et al. (2006) find that "net entry accounts for virtually all of the labor productivity growth in retail trade." (p. 757). However, besides showing that establishments belonging to large chains have the highest productivity levels (see Sect. 5.1), Foster et al. show that "Much of the contribution of net entry to overall productivity growth is associated with the displacement of single-unit establishments by the entry of highly productive establishments from national chains." (p. 757). Hence, their evidence might not relate to our notion of an entrepreneur.

To conclude, the evidence suggests, though not unambiguously, that labor productivity growth is higher in entrepreneurial firms than in other firms. ${ }^{21}$ Both studies based on micro- and macro-data show that the effect of increased entrepreneurial activity engenders labor productivity growth.

As in the previous section, a remark is in order. Whereas one of the three micro-studies using firmspecific data distinguishes entrepreneurs from others based on firm size, two of the three studies distinguish entrants from incumbents/exits and do so based on analyses of establishments rather than firms. Hence, these entrants possibly belong to incumbent (and large scale) chains. Both of the studies, i.e., Foster et al. (2006) and Disney et al. (2003), acknowledge that the contribution in productivity growth of entrants is mainly due to entering establishments of larger chains. This does not correspond to our notion of the entrepreneur.

The growth of Total Factor Productivity (TFP) represents growth in production due to a more efficient use of production factors. Three microstudies have measured the relative contribution of entrepreneurs to TFP growth, two of these for the Spanish manufacturing sector. Callejon and Segarra (1999) show that both entry and exit rates contribute positively to the growth of TFP in industries and regions. This leads thus to the conclusion that entrepreneurial activity is related positively to TFP growth. Castany et al. (2005) show that the growth rates of TFP levels in Spanish manufacturing firms appear rather similar for small and large firms. Their

Footnote 20 continued

sector, the majority of the net entry effect is caused by 'nonentrepreneurial' entrants.

21 Wong et al. (2005) show that only specific types of entrepreneurs engender growth. 
evidence is (only) based on descriptive statistics. Using more advanced statistical methods, Disney et al. find that establishment entry (net of establishment exits) is responsible for $80-90 \%$ of industrywide TFP growth. Thus, entrepreneurs would have very high contributions to TFP growth. However, as was the case with labor productivity, the effect of net entry is dominated by establishment groups, contributing three times more to TFP growth than single-unit establishments. We conclude that, if anything, entrepreneurs contribute to TFP growth proportionally.

Based on all the results described in this section, we conclude that entrepreneurs experienced higher growth in production value and labor productivity than their counterparts, see Table 9. The evidence for growth in TFP levels is meager. The results pertaining to studies where the definition of the entrepreneur is a new entering plant or establishment should be interpreted with great caution since entrants can belong to existing large chains and this group of entrants turns out to experience relatively high growth, but is not necessarily entrepreneurial.

\subsection{Summary of the contributions to productivity and growth}

We used several indicators to measure productivity and growth, assuming that the indicators are complementary to each other. Given that the studies observe different periods, sample sizes, and countries, while using various methodologies, the similarity of the findings is striking. Entrepreneurs may lag behind in the levels of productivity, but they are catching up to the production efficiency of the control group due to a higher growth rate.

\section{Contributions to utility}

This section will address whether individuals, given their personal characteristics, are better off being selfemployed or a business owner (i.e., entrepreneurs) than being wage-workers. 'Better off' is understood as having a higher utility level, and the indicators used are remuneration levels (Sect. 6.1), remuneration inequality and volatility (Sect. 6.2) and job satisfaction (Sect. 6.3).

\subsection{Remuneration levels}

An insightful comparison of the levels of 'incomes' of entrepreneurs relative to employees requires dealing with various measurement issues (see Parker 2004, pp. 14-16). Three different measures of entrepreneurs' incomes are compared to employees' incomes: (i) net profit; (ii) a periodic wealth transfer from the firm to the entrepreneur, much like a regular wage, labeled 'draw', and (iii) draw plus changes in the firm's equity value (Hamilton 2000). However, just comparing mean levels does not suffice, as the distribution of entrepreneurs' incomes is very different from the distribution of employees' incomes. The variance is larger and the distribution is more skewed, see below. Due to the presence of some 'superstar' 22 entrepreneurs, "mean earnings may not characterize the self-employment returns of the majority of business owners." (Hamilton 2000, p. 605). Therefore, comparisons based on averages are likely to produce different results from those based on medians or other quantiles of the income distribution. Another issue, which has not been addressed much, but has been widely recognized, is that entrepreneurs' incomes relative to those of employees may be underestimated due to under-reporting (Feldman and Slemrod 2007; Parker 2004) or overestimated due to omitting negative incomes from empirical studies (Van der Sluis and Van Praag 2007).

Hamilton (2000) is, in fact, the only study in our sample that analyzes the income differentials between entrepreneurs and wage employees very thoroughly (for the three different measures of entrepreneurial income, as well as for various quantiles of their distributions) for a broad sample of the US male population. His results show that entrepreneurs have lower median incomes than employees, i.e., that entrepreneurs "have both lower initial earnings and lower earnings growth than in paid employment, implying a median earnings differential of $35 \%$ for individuals in business for 10 years." (p. 604). The differences are smaller (or even of the opposite sign, dependent on the definition of entrepreneurial income) when average income levels are compared. The negative relative income for entrepreneurs is supported by the more recent findings of

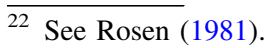




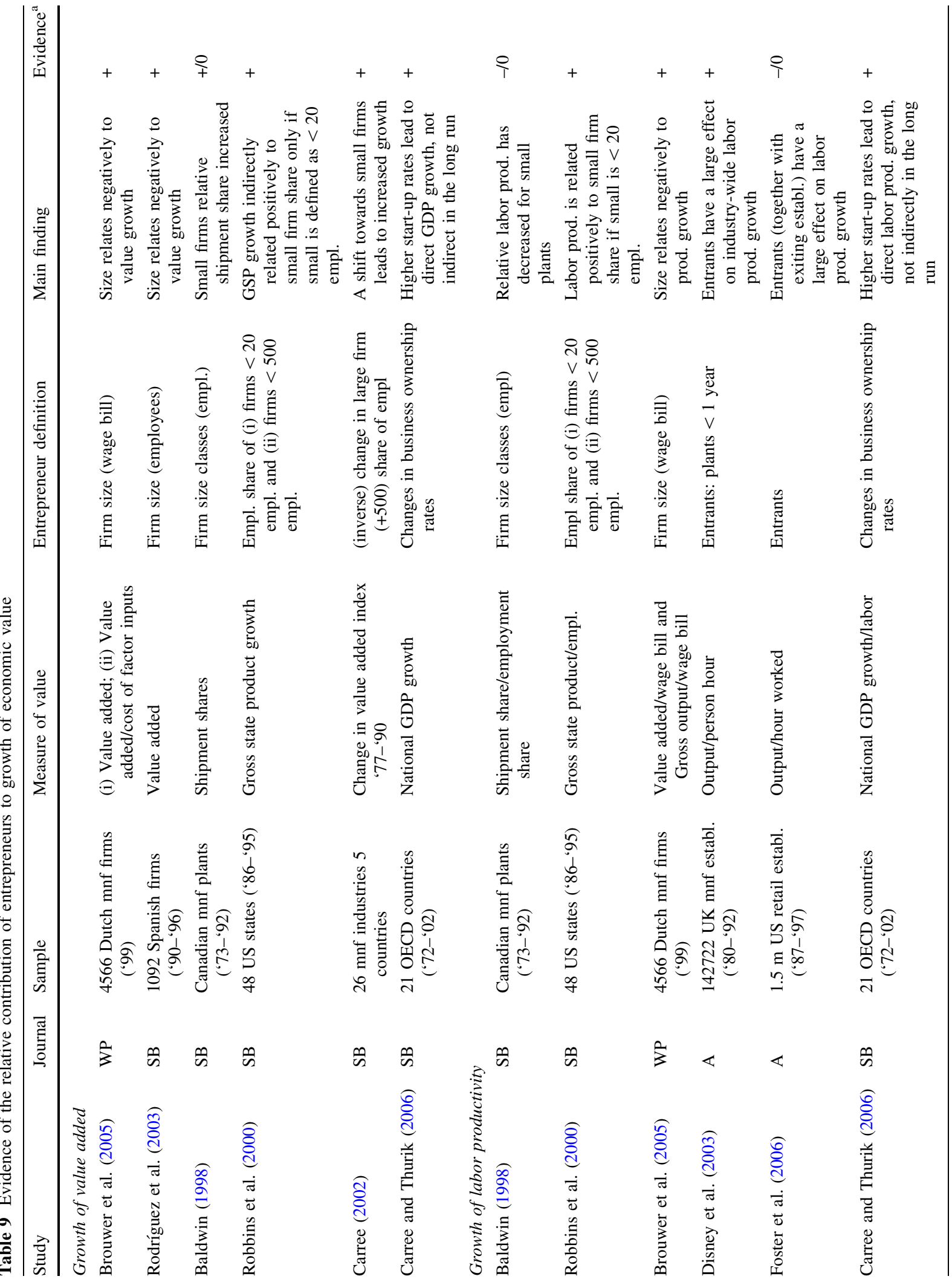


Kawaguchi (2002). Hamilton shows convincingly that the differential cannot be explained by the selection of low-ability employees into self-employment and is similar for three alternative measures of self-employment earnings and across industries. On average, entrepreneurs would benefit from higher incomes and higher growth rates of their incomes had they switched to employment. The upper quartile of the entrepreneurs' income distribution forms the exception. "Overall, it appears that many workers are willing to enter and remain in selfemployment despite receiving returns substantially below their alternative paid employment wage." (p. 606). Hamilton concludes that "The non-pecuniary benefits of self-employment are substantial: Most entrepreneurs enter and persist in business despite the fact that they have both lower initial earnings and lower earnings growth than in paid employment.” (p. 606).

Rosen and Willen (2002), on the contrary, find that entrepreneurs-given their educational level-and controlling for personal characteristics including gender, have higher mean and median income levels than wage-workers. Fairlie (2005) corroborates this results for male youth from disadvantaged families in the US based on average income levels (and the profit definition of entrepreneurial incomes). Fairlie controls for unobserved heterogeneity in individual characteristics by estimating a (individual) fixed effects model. ${ }^{23}$

Holtz-Eakin et al. (2000) analyze the mobility of individuals in the income distribution. They attempt to predict the change in the individual's percentile position, conditional upon being self-employed or a wage-worker. Among the low-earning individuals, the self-employed experience higher income growth than wage workers, keeping characteristics constant. In contrast, among the top-earning individuals, the self-employed experience smaller income growth than wage-workers. This suggests that the individual's benefit from being self-employed depends on her initial income. This result is in line with the combination of Hamilton's and Fairlie's findings.

\footnotetext{
$\overline{23}$ The results are sensitive to changes in the definition of the dependent variable. Male entrepreneurs earn significantly more than male wage workers with absolute incomes as the dependent variable, whereas the difference is insignificant when the logarithm of incomes is used.
} 
However, the study's basic model may produce a "regression-to-the-mean" effect (as noted by HoltzEakin et al. 2000; Pannenberg and Wagner 2001)

Van der Sluis et al. (2006) estimate income equations for a combined panel sample of entrepreneurs and employees from the US population (NLSY). By including interactions of one's occupational status, i.e., entrepreneur or employee, with all the usual control variables in the (log hourly) income equation, they allow the returns to various characteristics to be different for entrepreneurs and employees. The remaining unexplained differential in average incomes between entrepreneurs and employees turns out insignificantly different from zero. Based on the same dataset, Hartog et al. (2007) estimate income equations for entrepreneurs and employees in order to quantify the returns to (various kinds of) intelligence and ability for entrepreneurs vis-à-vis employees. Before allowing the returns to the various kinds of intelligence, ability and education to differ between entrepreneurs and employees (again by including interaction terms), they find that entrepreneurs earn approximately $9 \%$ lower incomes than employees, on average. However, as soon as they allow the returns to these measures of human capital to differ between the groups, the unexplained difference between entrepreneurs' and employees' income turns out insignificant.

In short, entrepreneurs in the US seem to earn lower median incomes than wage employees. However, for the upper and lower parts of the income distribution, the differences can be positive. Average incomes seem to be of similar levels for entrepreneurs and employees in regression frameworks that allow the returns to broad sets of indicators of human capital to differ across entrepreneurs and employees. Entrepreneurship might be good for social mobility and for becoming a 'super income earner'.

\subsection{Remuneration inequality and volatility}

One of the stylized facts in the economics of entrepreneurship is that the distribution of entrepreneurs' incomes is much less equal, i.e., has a higher variance, than the income distribution of wageemployees. Descriptive statistics of the income distributions of entrepreneurs and employees (mostly in terms of their averages and variances) in numerous studies have supported this claim (see Parker 2004 and all studies mentioned in the previous section). In most studies, negative incomes are equated to zero (Van der Sluis and Van Praag 2007; Parker 2004). Since entrepreneurs' incomes can be negative, whereas this is impossible for wage workers, this would only add to the difference in variance already observed. Hence, income inequality and uncertainty is higher for entrepreneurs than for employees. However, it should be noted that this observation is based on an unconditional comparison of crosssectional variances.

To assess income uncertainty for individual labor market participants, insight should be obtained in the variance of income over time for a given individual, i.e., income volatility. Carrington et al. (1996) investigate how entrepreneurs' and wage-workers' hourly incomes are affected by changes in the unemployment rate and GNP, i.e., events related to systematic risk. Based on a large sample of individuals in the US observed from 1967 to 1992 , the authors conclude that the incomes of entrepreneurs are significantly more responsive to both decreases and increases in the GNP and the unemployment rate, ceteris paribus. This is consistent with relatively risky entrepreneurial incomes. This conclusion is supported by Van der Sluis et al. (2006) and Rosen and Willen (2002) who assess whether entrepreneurial incomes are more risky for a given individual in terms of variances in incomes over time conditional on a broad set of individual characteristics. Thus, entrepreneurial incomes are riskier and more volatile than the incomes of employees, for otherwise identical individuals.

\subsection{Job satisfaction}

Job satisfaction scores are important indicators of utility levels. Blanchflower and Oswald (1998) show in their seminal article "What makes an entrepreneur?" that (i) entrepreneurs are significantly more satisfied with their work than wage workers on average; (ii) Entrepreneurs are significantly more satisfied with their work, controlling for various individual and work-related characteristics; (iii) The same holds for 'life satisfaction'. Their satisfaction data and findings pertain to the US. 
Benz and Frey (2003) execute a similar study pertaining to various countries and time periods and reach the same conclusion. They study the causes of job satisfaction by incorporating many job characteristics into the regressions. The difference in satisfaction levels between entrepreneurs and employees decreases, or even becomes insignificant, upon including controls for the individuals' evaluation of job content and autonomy. We can infer that entrepreneurs are more satisfied, mainly due to them having more interesting jobs and/or more autonomy.

Hence, these results collectively provide some evidence that entrepreneurs get higher utility than employees. But as Blanchflower and Oswald state "One caveat should be borne in mind when interpreting this study's findings. It may be that reported satisfaction levels are subject to important biases. For example, self-employed people may be intrinsically more optimistic and cheerful than others." (p. 49). Frey and Benz (2003) address this critique, by studying changes in satisfaction levels for individuals who change employment status, i.e., from entrepreneur to employee and vice versa or from job to job in wage employment for the UK and Western Germany. Individuals flowing into selfemployment are more satisfied than those flowing out of self-employment. Furthermore, those becoming entrepreneurs are also more satisfied than wageworkers that change their job (but remain wageworkers). Hence, these results, unaffected by unobserved individual differences, such as the extent of cheerfulness or optimism, are also supportive of higher satisfaction levels for entrepreneurs than for employees.

\subsection{Summary of utility levels}

The main question posed was: Is an individual with a given set of characteristics better off being an entrepreneur? The answer is interesting. Although entrepreneurs have lower median incomes, that are more volatile and less secure, they are more satisfied with both their jobs and their lives. Table 10 provides an overview.

What could explain this result? Do entrepreneurs severely under-report their incomes (Feldman and Slemrod 2007; Parker 2004)? Do entrepreneurs not mind that their incomes are more volatile because they are less risk averse ${ }^{24}$ This cannot be the entire explanation since switchers into entrepreneurship gain more satisfaction than switchers in the opposite direction (Frey and Benz 2003). Does entrepreneurship require start-up capital that many people are not able to acquire (e.g., Astebro and Bernhardt 2005)? Does entrepreneurship bring so much non-pecuniary benefits? These questions require more research.

\section{Conclusion}

We have reviewed the fruits from 12 years of highquality empirical research into the economic value of entrepreneurship. The research reviewed was selected based on specific rules such that statistical measurement of the relative benefits to the creation of economic value by entrepreneurs is enabled. Entrepreneurs or entrepreneurial firms are defined as small firms, young firms, entrants or self-employed. Their counterparts are defined as bigger firms, older firms, incumbent firms, or wage employees, respectively. At a more aggregated level, these definitions of entrepreneurship translate into the share of small or young firms, the number of entering firms as compared to the number of employees or incumbent firms in a region or country, and the rate of self-employment. Economic benefits are defined in terms of employment generation and dynamics, innovation, productivity and growth, and the creation of utility. The picture that emerges, both about the state of research and the results, is scattered.

The sample consists of 57 studies that analyze 87 relationships between entrepreneurship and economic outcomes. This sample size, in combination with the great variety of indicators of economic outcomes, countries, time periods and industries that have been studied, while using various definitions of the entrepreneur, does not (yet) allow a genuine meta-analysis. The small number of studies might be due to our strict requirements in terms of (journal) quality and the required explicit comparison between entrepreneurs and some control group. Nonetheless, our study has resulted in, rather complex, answers to the question: 'What is the economic value of entrepreneurs?' Table 11 serves as a guideline.

\footnotetext{
$\overline{{ }^{24} \text { Van Praag }}$ and Cramer (2001), Cramer et al. (2002), and Ekelund et al. (2005) are three studies providing evidence that individuals with higher risk aversion are less likely to become entrepreneurs.
} 


\subsection{Employment}

Entrepreneurs create more employment than their counterparts, relative to their size. This remains true when one accounts for the higher firm dissolution rate among entrepreneurial, i.e., young and small, firms which destroys jobs. Indeed, the net contribution of entrepreneurs to employment creation relative to their counterparts is positive. However, the net job creation of entrepreneurs goes along with a relatively high job destruction rate, leading to less job security and a more volatile process of employment creation. Hence, entrepreneurs do create more jobs, but they do so in a rather dynamic way, which is disadvantageous for the stability of the labor market. Another important aspect of entrepreneurial activity is the effect of new firm creation on the employment creation of incumbents. The evidence suggests rather convincingly that there is a positive long-term effect of more entrepreneurial activity on labor demand, also by non-entrepreneurial firms.

The quality of the jobs created by entrepreneurs is lower than for the counterparts. This is, among others, due to the fact that entrepreneurs hire employees with lower levels of human capital than other firms. However, even if one accounts as much as possible for all kinds of differences between entrepreneurial and other firms, such as the complementarity of capital and skills, and the differences in returns to skills that are paid to employees, an unexplained wage premium for employees in counterpart firms remains. Entrepreneurs pay not only lower wages, but also offer fewer benefits. However, apparently, entrepreneurs offer other intangible benefits to their employees because their employees are more satisfied with their (lower paid and less secure) jobs than the employees of their counterparts.

\subsection{Innovation}

Entrepreneurs do not spend more on R\&D than their counterparts. They produce fewer patents, new products and technologies. Moreover, the percentage of radical innovations is lower among entrepreneurial firms. Nevertheless, the efficiency with which innovations are produced seems to be higher and so is the quality of innovations as measured by the number of patent citations. Entrepreneurs commercialize innovations to a larger extent, but score lower on the adoption of innovations than their counterparts.

\subsection{Productivity and growth}

The relative contribution of entrepreneurs to the value of productivity levels is low. This holds for both labor and total factor productivity. However, entrepreneurs show relatively high growth rates of value added and productivity.

\subsection{Utility}

The majority of entrepreneurs would earn higher incomes as wage employees. The mean incomes of entrepreneurs can reach quite high levels due to some 'superstar' entrepreneurs. Nevertheless, the mean and median incomes of entrepreneurs appear to be lower or similar-but not higher-than the mean incomes of employees (conditional on various individual characteristics). This would lead to lower levels of utility. Entrepreneurs' incomes are also more variable over time than employee incomes, which reduces the utility of risk averse individuals, too. However, there must be various less tangible benefits to entrepreneurship like greater autonomy, or else, entrepreneurs are very irrational, optimistic, or risk seeking (or under-report their incomes): Entrepreneurs have higher levels of job satisfaction than employees.

All in all, we conclude that entrepreneurs have a very important-but specific-function in the economy. They engender relatively high levels of employment creation, productivity growth and produce and commercialize high-quality innovations. They are more satisfied than employees. However, the counterparts cannot be missed as they account for scale in terms of labor demand and GDP, a less volatile and more secure labor market, higher paid jobs and a greater number of innovations and the adoption of innovations.

We refrain from discussing the implications these findings have for policymakers. While most of the studies reviewed in the paper give certain proposals based on their respective findings, we acknowledge the limitations of our analysis. Our analysis allows conclusions about the relative contribution of entrepreneurs to the various economic areas, but we have 


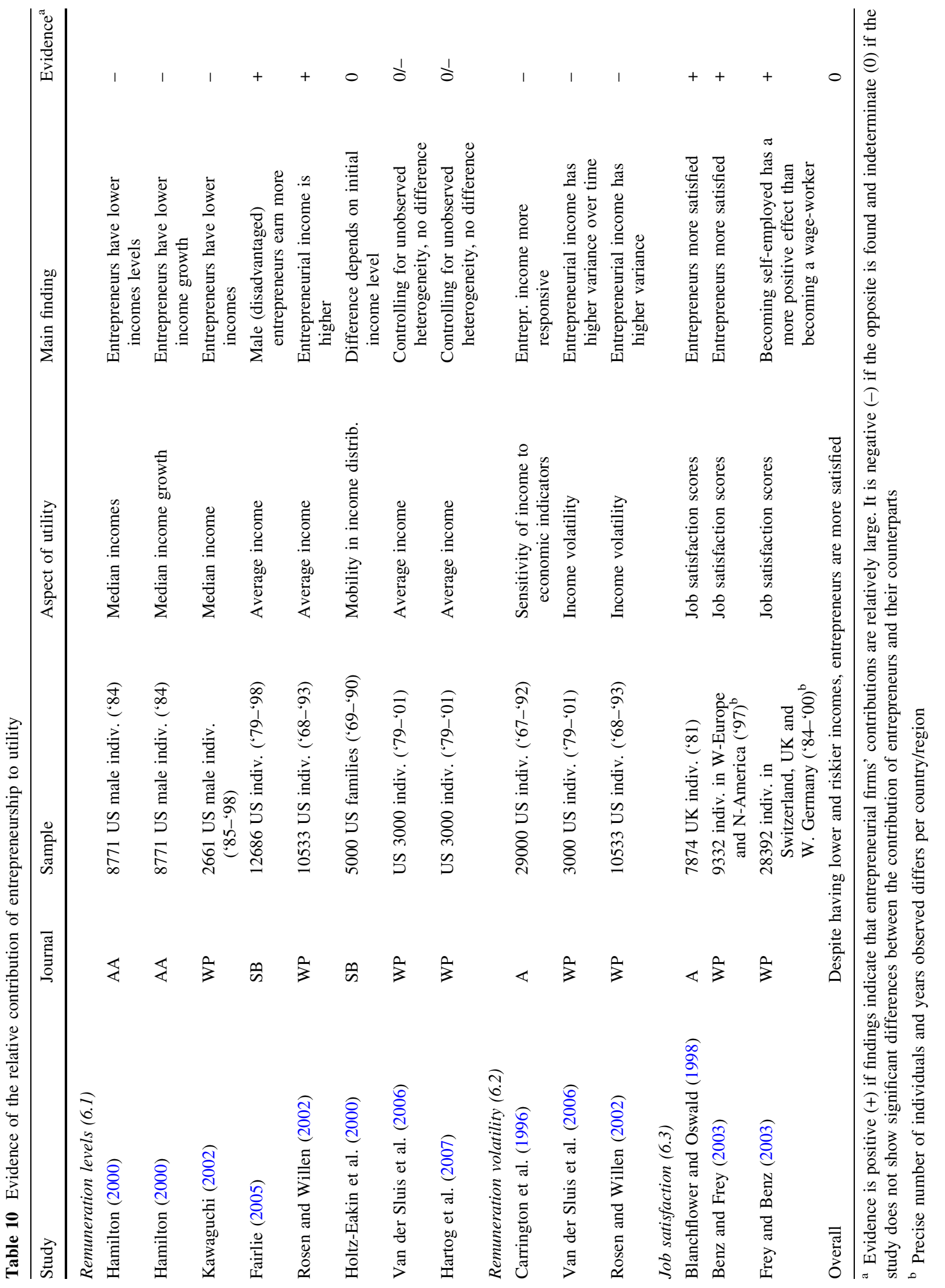


Table 11 Overview of the results

\begin{tabular}{|c|c|c|c|c|c|c|}
\hline Category & $\begin{array}{l}\text { Specification } \\
\text { of category }\end{array}$ & Sub-category & Studies & Positive & Zero & Negative \\
\hline Employment & Employment quantity & Employment generation & 15 & 14 & 0 & 1 \\
\hline Employment & Employment quantity & Employment dynamics & 2 & 0 & 0 & 2 \\
\hline Employment & Employment quality & Wage levels & 5 & 0 & 0 & 5 \\
\hline Employment & Employment quality & Benefits & 2 & 0 & 0 & 2 \\
\hline Employment & Employment quality & Job satisfaction & 3 & 2 & 0 & 1 \\
\hline Innovation & Innovations quantity & R\&D expenses per employee & 2 & 1 & 0 & 1 \\
\hline Innovation & Innovations quantity & Number/frequency of patents & 2 & 0 & 0 & 2 \\
\hline Innovation & Innovations quantity & New products and technologies & 2 & 0 & 0 & 2 \\
\hline Innovation & Innovations quantity & $\begin{array}{l}\text { New products and } \\
\text { technologies/employee }\end{array}$ & 1 & 1 & 0 & 0 \\
\hline Innovation & Innovations Quantity & $\begin{array}{l}\text { Percentage of radical } \\
\text { innovations }\end{array}$ & 1 & 0 & 0 & 1 \\
\hline Innovation & Innovations quality & $\begin{array}{l}\text { Self-assessed importance of } \\
\text { innovations }\end{array}$ & 1 & 0 & 0 & 1 \\
\hline Innovation & Innovations quality & Patent citations & 1 & 1 & 0 & 0 \\
\hline Innovation & $\begin{array}{l}\text { Commercialization of } \\
\text { innovations }\end{array}$ & $\begin{array}{l}\text { Commercialization of } \\
\text { innovations }\end{array}$ & 6 & 4 & 1 & 1 \\
\hline Innovation & Adoption of innovations & Adoption of innovations & 5 & 1 & 2 & 2 \\
\hline Productivity and growth & Value & Labor productivity & 4 & 1 & 0 & 3 \\
\hline Productivity and growth & Value & Total factor productivity & 4 & 1 & 1 & 2 \\
\hline Productivity and growth & Growth & Growth of value added & 7 & 6 & 1 & 0 \\
\hline Productivity and growth & Growth & Growth of labor productivity & 7 & 5 & 0 & 2 \\
\hline Productivity and growth & Growth & $\begin{array}{l}\text { Growth of total factor } \\
\text { productivity }\end{array}$ & 3 & 2 & 1 & 0 \\
\hline Utility & Remuneration levels & Remuneration levels & 8 & 2 & 1 & 5 \\
\hline Utility & Remuneration volatility & Remuneration volatility & 3 & 0 & 0 & 3 \\
\hline Utility & Satisfaction & Satisfaction & 3 & 3 & 0 & 0 \\
\hline Total & & & 87 & 44 & 7 & 36 \\
\hline
\end{tabular}

not investigated the possible causes. This warrants an entire study in itself. Moreover, interrelationships may exist between the types of contributions we have considered and spillover effects to non-entrepreneurial firms, especially at the regional level (Scott 2006). Some research into these interrelationships has been initiated recently and discussed here. It is clear from this handful of studies that indirect spillover effects in all areas cannot be ignored and that they should be measured much more extensively. For example, it may well be that a more profitable entrepreneurial firm is better (or less) able at facilitating employment and producing innovations, whereas the innovativeness of entrepreneurs may be the result of nonentrepreneurial firms in the same area and/or sector that produce innovations. Such interrelationships and spillover effects should be measured and taken into account when designing policy. ${ }^{25}$

Acknowledgments The authors are grateful to Andre van Stel, David Audretsch, Zoltan Acs, Thomas Hellman, Randolph Sloof and Niels Bosma for their helpful comments. A longer and extended version of the article is published as Van Praag, C. Mirjam and Peter Versloot, "The Economic Benefits and Costs of Entrepreneurship: A Review of the Research", Foundations and Trends in Entrepreneurship, 4:2, 2008, pp 63-152. The usual disclaimer applies.

\footnotetext{
${ }^{25}$ Hewitt-Dundas (2006), for instance, shows that the factors constraining firms' ability to innovate are very different for small firms than for large firms. Thus, policy to stimulate innovations would therefore be different when targeted to large firms than to small firms
} 


\section{References}

Acs, Z. J., \& Audretsch, D. B. (2005). Entrepreneurship, innovation and technological change. Foundations and Trends in Entrepreneurship, 1(4), 1-65.

Acs, Z. J., \& Gifford, S. (1996). Innovation of entrepreneurial firms. Small Business Economics, 8(3), 203-218.

Acs, Z. J., \& Mueller, P. (2007). Employment effects of business dynamics: Mice, gazelles and elephants. Small Business Economics, doi: 10.1007/s11187-007-9052-3.

Acs, Z. J., \& Varga, A. (2005). Entrepreneurship, agglomeration and technological change. Small Business Economics, 24(3), 323-334.

Almeida, P., \& Kogut, B. (1997). The exploration of technological diversity and the geographic localization of innovation. Small Business Economics, 9(1), 21-31.

Anyadike-Danes, M., Hart, M., \& O'Reilly, M. (2005). Watch that space! The county hierarchy in firm births and deaths in the UK, 1980-1999. Small Business Economics, 25(3), 273-292.

Arvanitis, S. (1997). The impact of firm size on innovative activity-an empirical analysis based on Swiss firm data. Small Business Economics, 9(6), 473-490.

Astebro, T., \& Bernhardt, I. (2005). The winner's curse of human capital. Small Business Economics, 24(1), 63-78.

Audretsch, D. B., Carree, M. A., Van Stel, A. J., \& Thurik, A. R. (2002). Impeded industrial restructuring: The growth penalty. Kyklos, 55, 81-98.

Audretsch, D. B., \& Vivarelli, M. (1996). Firm size and R\&D spillovers: Evidence from Italy. Small Business Economics, 8(3), 249-258.

Baldwin, J. R. (1998). Were small producers the engines of growth in the Canadian manufacturing sector in the 1980s? Small Business Economics, 10(4), 349-364.

Baldwin, J., \& Picot, G. (1995). Employment generation by small producers in the Canadian manufacturing sector. Small Business Economics, 7(4), 317-331.

Baptista, R., Escaria, V., \& Madruga, P. (2007). Entrepreneurship, regional development and job creation: The case of Portugal. Small Business Economics, doi: 10.1007/s11187-007-9055-0.

BarNir, A., Gallaugher, J. M., \& Auger, P. (2003). Business process digitization, strategy, and the impact of firm age and size: The case of the magazine publishing industry. Journal of Business Venturing, 18(6), 789-814.

Benz, M., \& Frey, B. S. (2003). The value of autonomy: Evidence from the self-employed in 23 countries. University of Zurich Working Paper \#173, Zurich, Switzerland.

Biggs, T. (2002). Is small beautiful and worthy of subsidy? International Finance Corporation, Washington, USA. Link: http://www.rru.worldbank.org/PapersLinks/Open. aspx ?id=2482.

Blanchflower, D. G., \& Oswald, A. J. (1998). What makes an entrepreneur? Journal of Labor Economics, 16(1), 26-60.

Broersma, L., \& Gautier, P. (1997). Job creation and job destruction by small firms: An empirical investigation for the Dutch manufacturing sector. Small Business Economics, 9(3), 211-224.

Brouwer, E., \& Kleinknecht, A. (1996). Firm size, small business presence and sales of innovative products: A micro-econometric analysis. Small Business Economics, 8(3), 189-201.

Brouwer, P., De Kok, J., \& Fris, P. (2005). Can firm age account for productivity differences? EIM SCALES-paper N200421, Zoetermeer, Netherlands.

Brown, C., \& Medoff, J. L. (2003). Firm age and wages. Journal of Labor Economics, 21(3), 677-697.

Burgess, S., Lane, J., \& Stevens, D. (2000). Job flows, worker flows, and churning. Journal of Labor Economics, 18(3), 473-502.

Callejon, M., \& Segarra, A. (1999). Business dynamics and efficiency in industries and regions: The case of Spain. Small Business Economics, 13(4), 253-271.

Calvo, J. L. (2006). Testing Gibrat's law for small, young, and innovating firms. Small Business Economics, 26(2), 117-123.

Carree, M. A. (2002). Industrial restructuring and economic growth. Small Business Economics, 18, 243-255.

Carree, M. A., \& Thurik, A. R. (2003). The impact of entrepreneurship on economic growth. In Z. J. Acs \& D. B. Audretsch (Eds.), Handbook of entrepreneurship research (pp. 437-471). Boston, MA: Kluwer Academic Publishers.

Carree, M. A., \& Thurik, A. R. (2006). The lag structure of the impact of business ownership on economic performance in OECD countries. Small Business Economics, doi: 10.1007/s11187-006-9007-0.

Carrington, W. J., McCue, K., \& Pierce, B. (1996). The role of employer/employee interactions in labor market cycles: Evidence from the self-employed. Journal of Labor Economics, 14(4), 571-602.

Castany, L., López-Bazo, E., \& Moreno, R. (2005). Differences in total factor productivity across firm size. A distributional analysis. University of Barcelona Working Paper.

Caves, R. E. (1998). Industrial organization and new findings on the turnover and mobility of firms. Journal of Economic Literature, 36(4), 1947-1982.

Chandrashekaran, M., \& Sinha, R. K. (1995). Isolating the determinants of innovativeness: A split-population tobit (SPOT) duration model of timing and volume of first and repeat purchase. Journal of Marketing Research, 32(August), 444-456.

Clark, A. E., \& Oswald, A. J. (1996). Satisfaction and comparison income. Journal of Public Economics, 61(3), 359-381.

Cowling, M. (2001). Fixed wages or productivity pay: Evidence from 15 EU countries. Small Business Economics, 16(3), 191-204.

Cramer, J. S., Hartog, J., Jonker N., \& Van Praag, C. M., (2002). Low risk aversion encourages the choice for entrepreneurship: An empirical test of a truism. Journal of Economic Behavior and Organization, 48(1), 29-36.

Czarnitzki, D., \& Kraft, K. (2004). Firm leadership and innovative performance: Evidence from seven EU countries. Small Business Economics, 22(5), 325-332.

Davis, S. J., \& Haltiwanger, J. (1992). Gross job creation, gross job destruction, and employment reallocation. The Quarterly Journal of Economics, 107(3), 819-863.

Davis, S. J., Haltiwanger, J., \& Schuh, S. (1996). Small business and job creation: Dissecting the myth and reassessing the facts. Small Business Economics, 8(4), 297-315. 
Dechenaux, E., Goldfarb, B., Shane, S. A., \& Thursby, M. C. (2003). Appropriability and the timing of innovation: Evidence from MIT inventions. NBER Working Paper 9735, Cambridge, MA, USA.

Disney, R., Haskal, J., \& Heden, Y. (2003). Restructuring and productivity growth in UK manufacturing. The Economic Journal, 113(July), 666-694.

Dunne, T., Roberts, M. J., \& Samuelson, L. (1988). Patterns of firm entry and exit in U.S. manufacturing industries. The RAND Journal of Economics, 19(4), 495-515.

Ekelund, J., Johansson, E., Järvelin, M. R., \& Lichtermann, D. (2005). Self-employment and risk aversion-evidence from psychological test data. Labour Economics, 12(5), 649-659.

Fairlie, R. W. (2005). Entrepreneurship and earnings among young adults from disadvantaged families. Small Business Economics, 25(3), 223-236.

Feldman, N. E., \& Slemrod, J. (2007). Estimating tax noncompliance with evidence from unaudited tax returns. Economic Journal, 117(518), 327-352.

Fölster, S. (2000). Do entrepreneurs create jobs? Small Business Economics, 14(2), 137-148.

Foster, L., Haltiwanger, J., \& Krizan, C. J. (2006). Market selection, reallocation, and restructuring in the U.S. retail trade sector in the 1990s. The Review of Economics and Statistics, 88(4), 748-758.

Frey, B. S., \& Benz, M. (2003). Being independent is a great thing: Subjective evaluations of self-employment and hierarchy. CESifo Working Paper \#959, Munich, Germany.

Fritsch, M. (1997). New firms and regional employment change. Small Business Economics, 9, 437-448.

Fritsch, M. (2007). How does new business formation affect regional development? Small Business Economics, doi: 10.1007/s11187-007-9057-y.

Fritsch, M., \& Mueller, P. (2007). The effect of new business formation on regional development over time. The case of Germany. Small Business Economics, doi: 10.1007/ s11187-007-9067-9.

Gibrat, R. (1931). Les Inégalités Economiques. Paris, France: Librairie du Recueil Sirey.

Hamilton, B. H. (2000). Does entrepreneurship pay? An empirical analysis of the returns to self-employment. The Journal of Political Economy, 108(3), 604-631.

Hart, P. E., \& Oulton, N. (1996). Growth and size of firms. The Economic Journal, 106(438), 1242-1252.

Hartarska, V., \& Gonzalez-Vega, C. (2006). What affects new and established firms' expansion? Evidence from small firms in Russia. Small Business Economics, 27(2), 195-206.

Hartog, J., Van der Sluis, J., \& Van Praag, M. (2007). Returns to intelligence: Entrepreneurs versus employees. University of Amsterdam Working Paper, Amsterdam, Netherlands.

Heshmati, A. (2001). On the growth of micro and small firms: Evidence from Sweden. Small Business Economics, 17(3), 213-228.

Hewitt-Dundas, N. (2006). Resource and capability constraints to innovation in small and large plants. Small Business Economics, 26(3), 257-277.
Holtz-Eakin, D., Rosen, H. S., \& Weathers, R. (2000). Horatio Alger meets the mobility tables. Small Business Economics, 14(4), 243-274.

Huergo, E., \& Jaumandreu, J. (2004). How does probability of innovation change with firm age? Small Business Economics, 22(3-4), 193-207.

Jensen, J. B., McGuckin, R. H., \& Stiroh, K. J. (2001). The impact of vintage and survival on productivity: Evidence from cohorts of U.S. manufacturing plants. The Review of Economics and Statistics, 83(2), 323-332.

Johansson, D. (2005). The turnover of firms and industry growth. Small Business Economics, 24(5), 487-495.

Kawaguchi, D. (2002). Compensating wage differentials among self-employed workers: Evidence from job satisfaction scores. Osaka University Working Paper, Osaka, Japan.

Koga, T. (2005). R\&D subsidy and self-financed R\&D: The case of Japanese high-technology start-ups. Small Business Economics, 24(1), 53-62.

Konings, J. (1995). Gross job flows and the evolution of size in U.K. establishments. Small Business Economics, 7(3), 213-220.

Kortum, S., \& Lerner, J. (2000). Assessing the contribution of venture capital to innovation. The RAND Journal of Economics, 31(4), 674-692.

Lever, M. H. C. (1996). Firm size and employment determination in Dutch manufacturing industries. Small Business Economics, 8(5), 389-396.

Love, J. H., \& Ashcroft, B. (1999). Market versus corporate structure in plant-level innovation performance. Small Business Economics, 13(2), 97-109.

Lowe, R. A., \& Ziedonis, A. A. (2006). Over-optimism and the performance of entrepreneurial firms. Management Science, 52(2), 173-186.

Lucchetti, R., \& Sterlacchini, A. (2004). The adoption of ICT among SMEs: Evidence from an Italian survey. Small Business Economics, 23(2), 151-168.

Luger, M. I., \& Koo, J. (2005). Defining and tracking business start-ups. Small Business Economics, 24(1), 17-28.

Maes, J., Sels, L., Roodhooft, F. (2005). Modeling the link between management practices and financial performance. Small Business Economics, 25(1), 17-34.

Mueller, P., Van Stel, A., \& Storey, D. (2007). The effects of new firm formation on regional development over time: The case of Great Britain. Small Business Economics, doi: 10.1007/s11187-007-9056-z.

Neumark, D., Zhang, J., \& Wall, B. (2005). Business establishment dynamics and employment growth. Available at SSRN: http://www.ssrn.com/abstract=909249.

Nguyen, S. V., \& Lee, S. H. (2002). Returns to scale in small and large U.S. manufacturing establishments: Further evidence. Small Business Economics, 19(1), 41-50.

Norton, W. I., \& Moore, W. T. (2006). The influence of entrepreneurial risk assessment on venture launch or growth decisions. Small Business Economics, 26(3), 215-226.

Nurmi, S. (2006). Sectoral differences in plant start-up size in the Finnish economy. Small Business Economics, 26(1), 39-59. 
Oliveira, B., \& Fortunato, A. (2006). Firm growth and liquidity constraints: A dynamic analysis. Small Business Economics, 27(2-3), 139-156.

Oosterbeek, H., \& Van Praag, M. (1995). Firm-size wage differentials in the Netherlands. Small Business Economics, 7(3), 173-182.

Pannenberg, M., \& Wagner, G. G. (2001). Overtime work, overtime compensation and the distribution of economic well-being. Evidence for the West Germany and Great Britain. IZA Discussion Paper \#318, Bonn, Germany.

Parker, S. C. (2004). The economics of self-employment and entrepreneurship. Cambridge, UK: Cambridge University Press.

Picot, G., \& Dupuy, R. (1998). Job creation by company size class: The magnitude, concentration and persistence of job gains and losses in Canada. Small Business Economics, 10(2), 117-139.

Robbins, D. K., Pantuosco, L. J., Parker, D. F., \& Fuller, B. K. (2000). An empirical assessment of the contribution of small business employment to U.S. state economic performance. Small Business Economics, 15(4), 293-302.

Rodríguez, A. C., Molina, M. A., Pérez, A. L. G., \& Hernández, U. M. (2003). Size, age and activity sector on the growth of the small and medium firm size. Small Business Economics, 21(3), 289-307.

Roper, S. (1999). Under-reporting of R\&D in small firms: The impact on international R\&D comparisons. Small Business Economics, 12(2), 131-135.

Rosen, S. (1981). The economics of superstars. The American Economic Review, 71(5), 845-858.

Rosen, H., \& Willen, P. (2002). Risk, return and self-employment. University of Chicago/Princeton University Discussion Paper, USA.

Scott, A. J. (2006). Entrepreneurship, innovation and industrial development: Geography and the creative field revisited. Small Business Economics, 26(1), 1-24.

Shaffer, S. (2006). Establishment size and local employment growth. Small Business Economics, 26(5), 439-454.

Solow, R. M. (1957). Technical change and the aggregate production function. The Review of Economics and Statistics, 39(3), 312-320.

Sørensen, J. B., \& Stuart, T. E. (2000). Aging, obsolescence, and organizational innovation. Administrative Science Quarterly, 45(1), 81-112.

Spletzer, J. R. (2000). The contribution of establishment births and deaths to employment growth. Journal of Business and Economic Statistics, 18(1), 113-126.
Sternberg, R., \& Wennekers, S. (2005). Determinants and effects of new business creation using global entrepreneurship monitor data. Small Business Economics, 24(3), 193-203.

Sutton, J. (1997). Gibrat's legacy. Journal of Economic Literature, 35(1), 40-59.

Troske, K. R. (1999). Evidence on the employer size-wage premium from worker-establishment matched data. The Review of Economics and Statistics, 81(1), 15-26.

Van der Sluis, J., \& Van Praag, C. M. (2007). Returns to education for entrepreneurs and employees: Identification by means of changes in compulsory schooling laws. University of Amsterdam Working Paper, Amsterdam, Netherlands.

Van der Sluis, J., Van Praag, M., \& Van Witteloostuijn, A. (2006). Why are the returns to education higher for entrepreneurs than for employees? University of Amsterdam Working Paper, Amsterdam, Netherlands.

Van Praag, C. M., \& Cramer, J. S. (2001). The roots of entrepreneurship and labor demand: Individual ability and low risk aversion. Economica, 68(269), 45-62.

Van Stel, A., \& Suddle, K. (2007). The impact of new firm formation on regional development in the Netherlands. Small Business Economics, doi: 10.1007/s11187-0079054-1.

Van Stel, A., Carree, M., \& Thurik R. (2005). The effect of entrepreneurial activity on national economic growth. Small Business Economics, 24(3), 311-321.

Wennekers, S., Van Stel, A., Thrurik, R., \& Reynolds, P. (2005). Nascent entrepreneurship and the level of economic development. Small Business Economics, 24(3), 293-309.

Winter-Ebmer, R., \& Zweimuller, J. (1999). Firm-size wage differentials in Switzerland: Evidence from job-changers. The American Economic Review, 89(2) Papers and Proceedings, 89-93.

Wong, P. K., Ho, Y. P., \& Autio, E. (2005). Entrepreneurship, innovation, and economic growth: Evidence from GEM data. Small Business Economics, 24(3), 335-350.

Wunnava, P. V., \& Ewing, B. T. (2000). Union-nonunion gender wage and benefit differentials across establishment sizes. Small Business Economics, 15(1), 47-57.

Wynarczyk, P., \& Watson, R. (2005). Firm growth and supply chain partnerships: An empirical analysis of U.K. SME subcontractors. Small Business Economics, 24(1), 39-51.

Yang, C.-H., \& Huang, C.-H. (2005). R\&D, size and firm growth in Taiwan's electronics industry. Business Economics, 25(5), 477-487. 